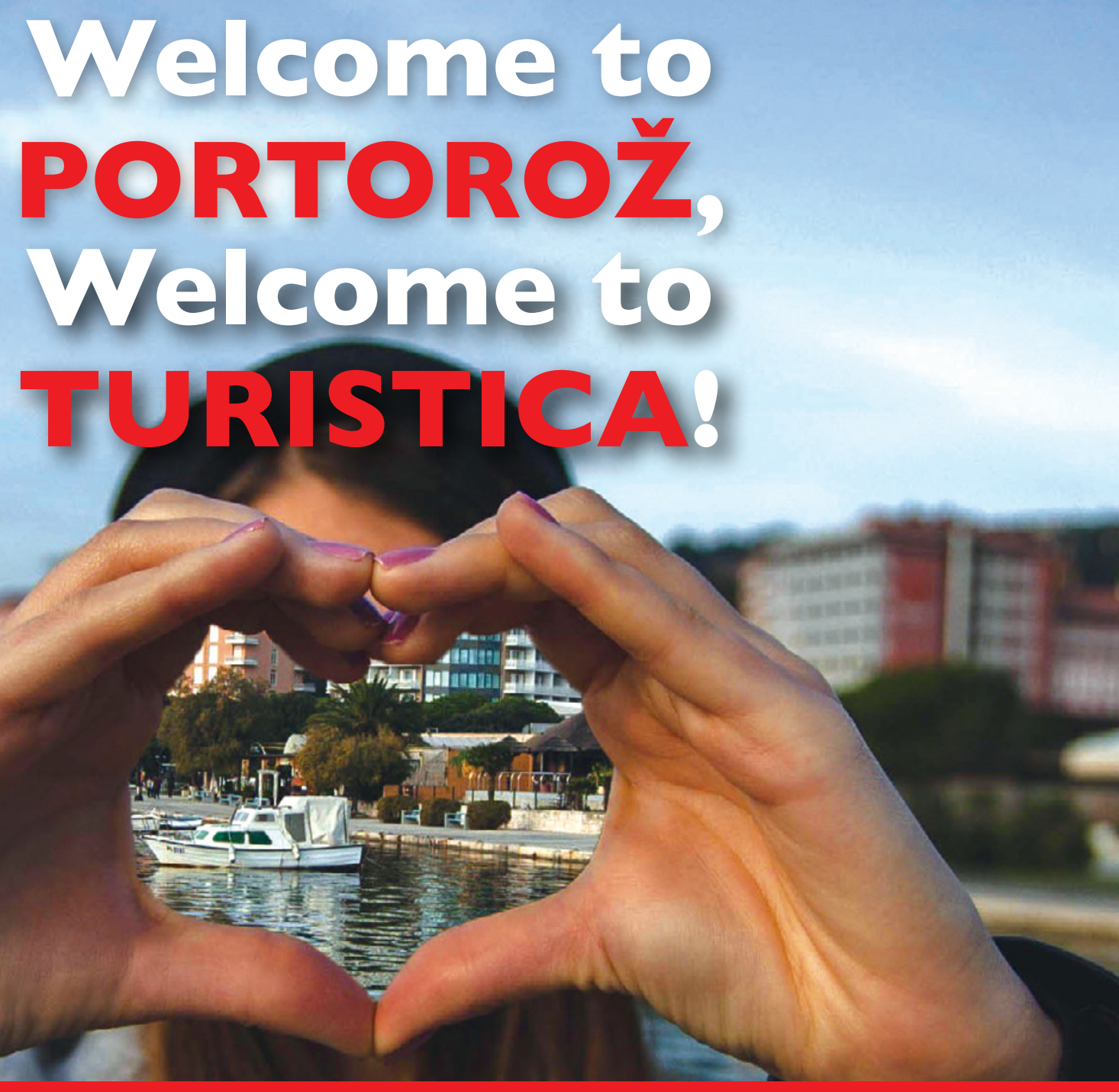

"Well-prepared students for a world-wide workplace" 


\section{Welcome to PORTOROŽ, Welcome to TURISTICA! \\ Welcome Guide for Foreign Students}

Edited by

Žana Čivre, Aleksandra Brezovec

Texts

Mariana Rodela, Nina Lovec, Tina Orel Frank

Cover Photo

Žan Tomažič

Photos by

Turistica archives; www.slovenia.info; Tourist board Porotorož;

www.le-potica.si; www.pixabay.com

Design and Typesetting

Face d.o.o.

Published by

University of Primorska Press

Titov trg 4, SI-6000 Koper

Editor-in-Chief

Jonatan Vinkler

Managing Editor

Alen Ježovnik

Koper, December 2019

ISBN 978-96 I-7055-87-0 (pdf): www.hippocampus.si/ISBN/978-96I-7055-87-0.pdf ISBN 978-96I-7055-88-7 (html): hippocampus.si/ISBN/978-96I-7055-88-7/index.html DOI: https://doi.org/ |0.26493/978-96|-7055-87-0

(C) University of Primorska 


\section{Welcome to PORTOROž, \\ Welcome to \\ TURISTICA! \\ Welcome Guide for Foreign Student}

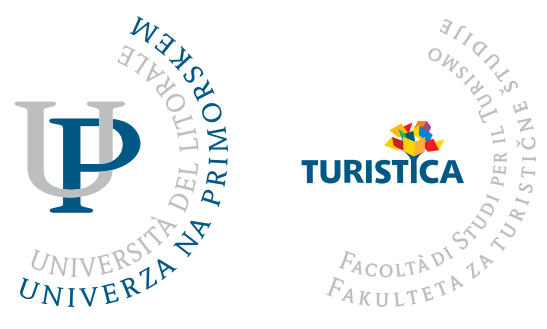




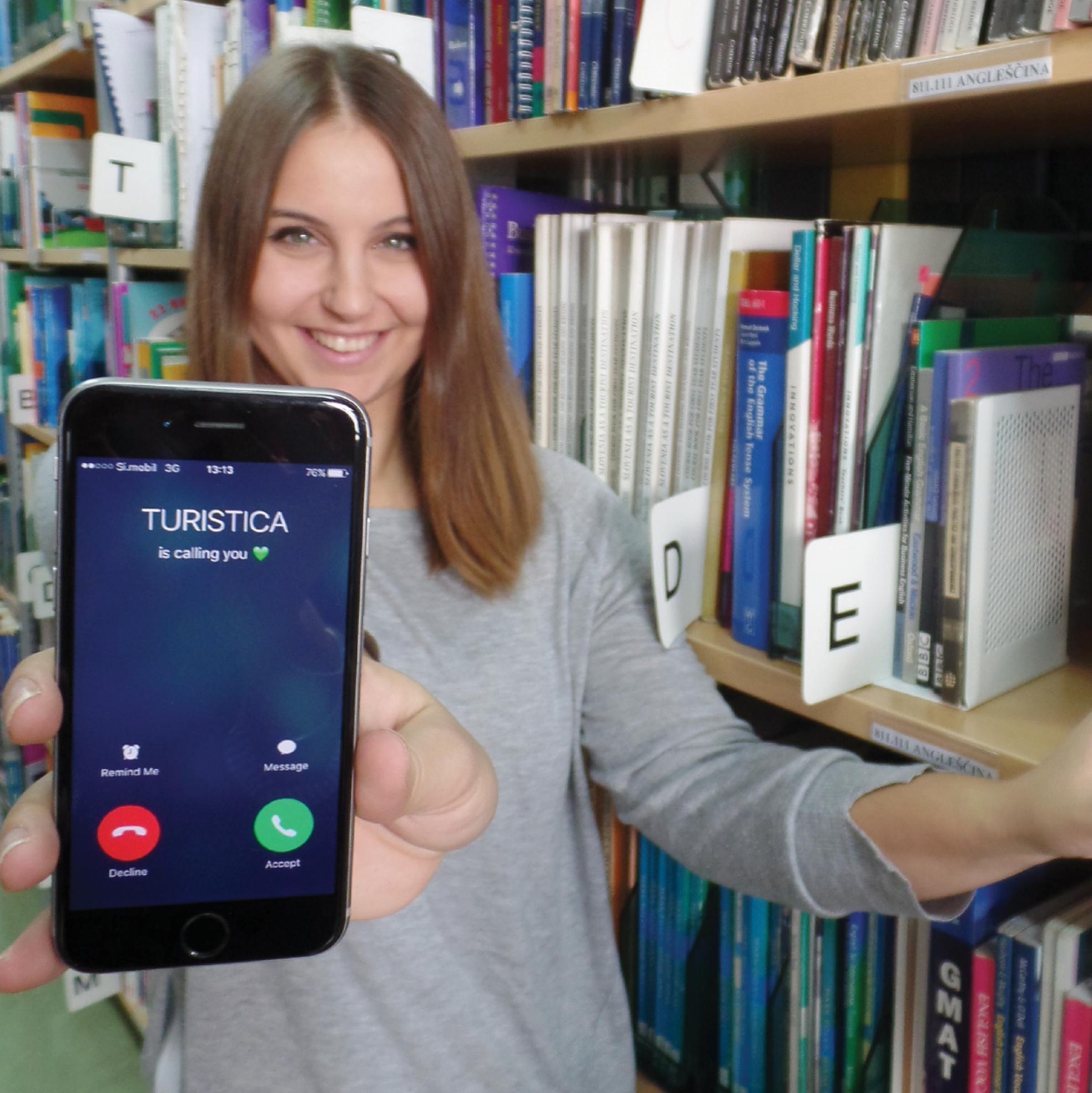




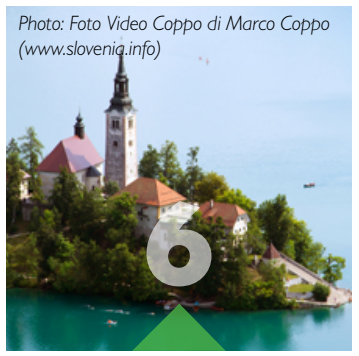

Welcome to Slovenia

Turistica in figures

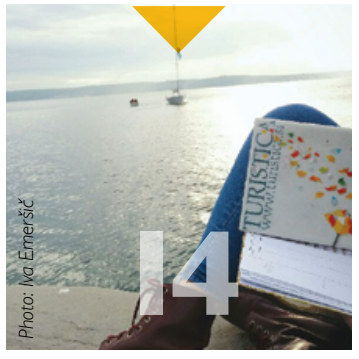

Table of Contents

Faculty of tourism studies - Turistica
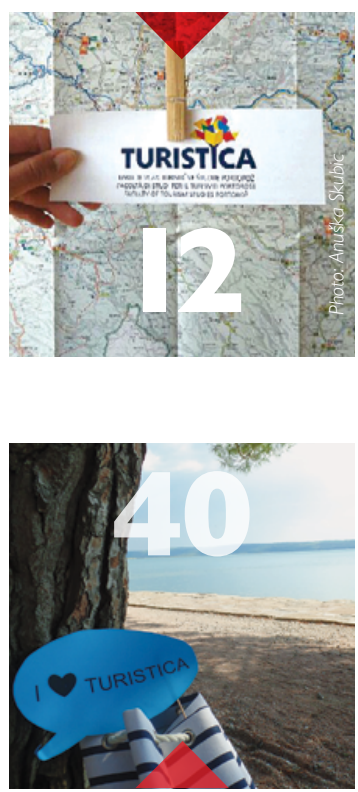

Student life at Tursitica

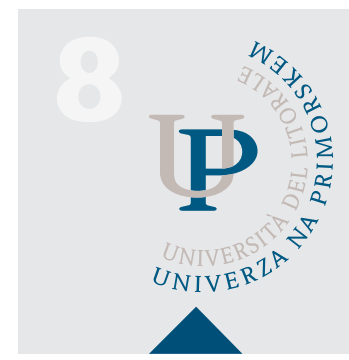

University of Primorska

Our students

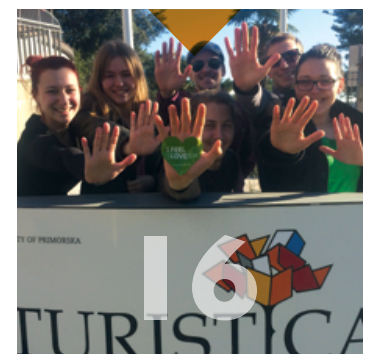

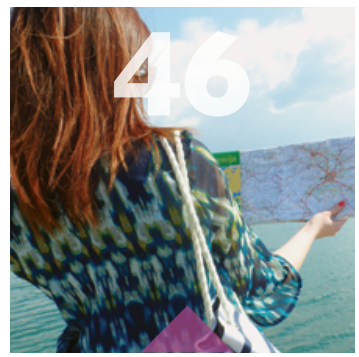

International cooperation

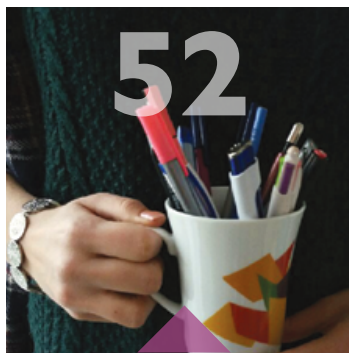

Employment

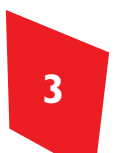

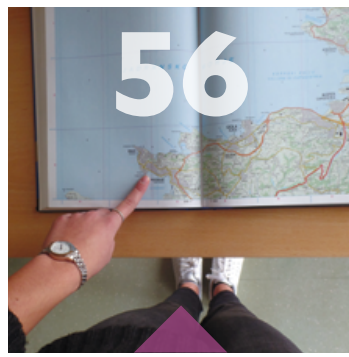

Enrollment for foreign citizens 


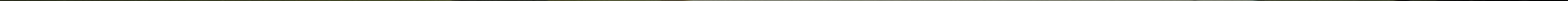




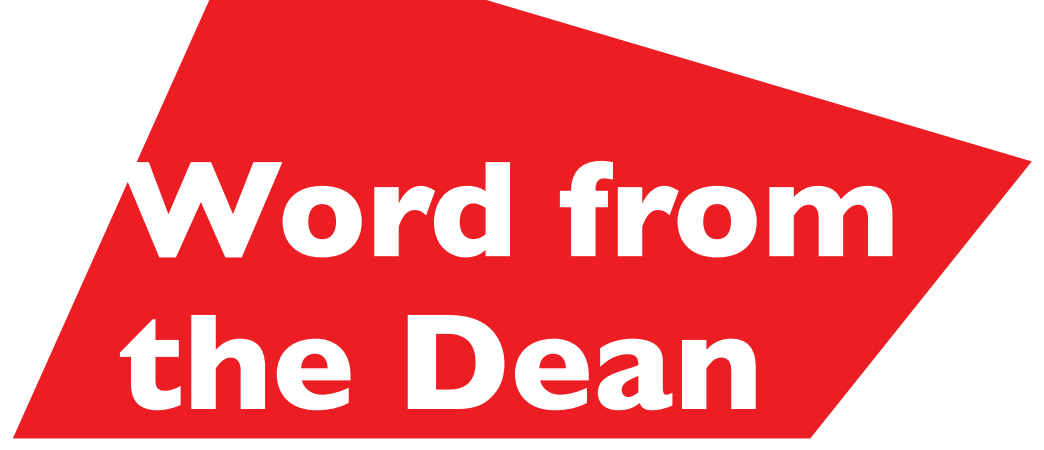

At the Faculty of Tourism Studies - Turistica we research, lecture and learn about a relatively fresh phenomenon, which in all of its forms attracts millions of people worldwide. We research this phenomenon which development and extent are synchronized with the degree of freedom, human rights and acceptance of diversity on our planet. What, more than tourism, can unite people and enrich individuals? Which phenomenon has gone beyond the understanding of the meaning of nature, its values and cultural heritage?

I believe that the power of unification held by tourism has been transferred to our Turistica as well and is reflected in our mutual relations. If journeys have always been driven by curiosity, then our research in tourism is driven by wit on top of curiosity as well. If ever, today is the time to emphasise the vision of Turistica as a leading Slovenian multidisciplinary educational and research institution in the field of tourism and its related activities, i.e. to become a referential faculty in Europe by acting globally. We will strive towards this aim via synergy, responsible work and good mutual relations. The latter are based on integration, trust, optimism, transparency and reciprocal tolerance, i.e. on the same values, which represent the foundations of modern tourism. The success of a tourism faculty can only be built by content people, employees and students, as successful tourism can only be built by satisfied tourists, guests and tourism employees. To understand life, one has to live it actively, and therefore we invite future students to join us and experience the life of our faculty. Turistica - the best fellow traveller - will accompany you on this journey. Enter the world of tourism through the doors of Turistica.
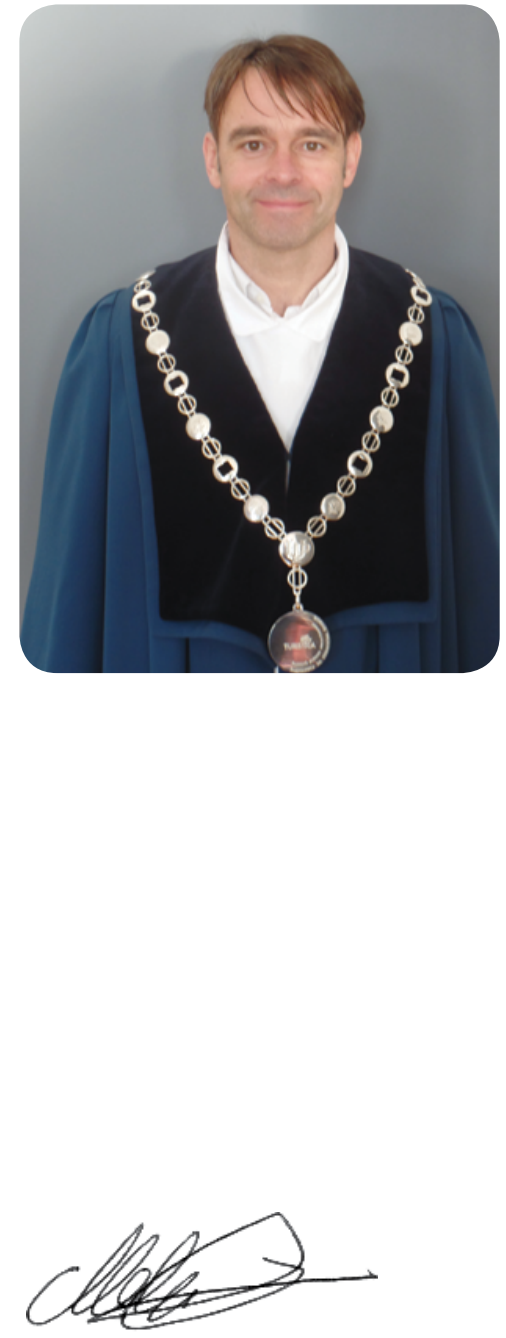

Dr. Janez Mekinc, Assoc. prof.

dean of Faculty of Tourism Studies Turistica, University of Primorska 



\section{DID YOU KNOW?}

Source: www.slovenia.info

... that the Sečovlje Salina Nature Park is the only Slovenian wetland area on the UNESCO list of wetlands of international importance? Today only a small section of the saltpans, which are more than 700 years old, is still used to make salt.

... that Maribor, Slovenia's second-largest city, is home to the oldest vine in the world? Although it is over four hundred years old, its Žametna Črnina grapes still produce 25 litres of wine every year.

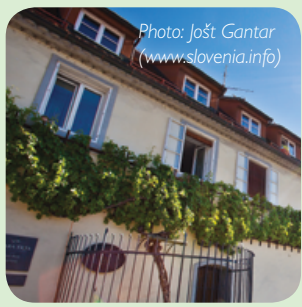
records in ski jumping and ski flying have been set in Planica? Ski jumpers in Planica were the first to break the magic 100-metre and 200-metre barriers.

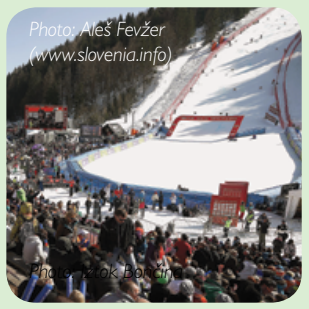

... that over 60 world

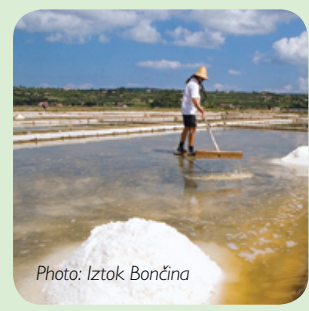

... that Slovenia has over 7,000 kilometers of mountain hiking trails, along which there are 165 mountain huts and bivouacs?

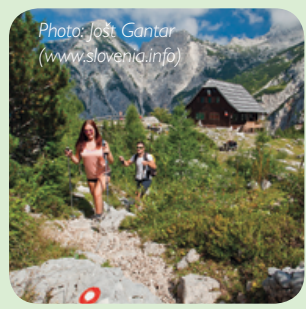

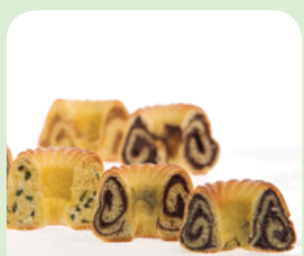

wuw.le-potica.si

... that a traditional Slovene dish for special occasions is a type of cake called potica? This has recently become one of the more recognizable symbols of Slovenia at a wide variety of international political, cultural and sporting events.

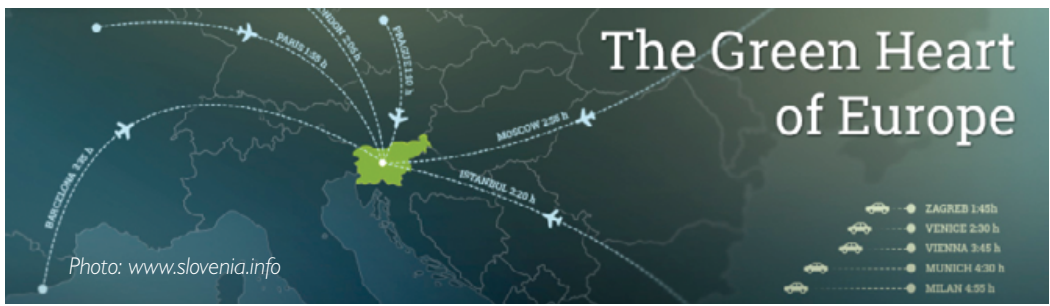

The Official slogan of Slovenia:

\section{FEEL SLOVENIA}

...that $216 \mathrm{~km}^{2}$ of Slovenia is covered by vineyards?

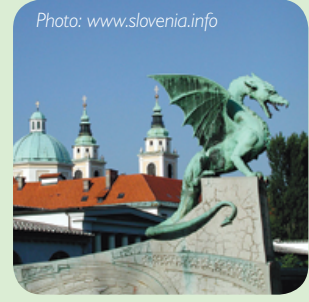

... that the official symbol of Ljubljana is a dragon which, according to a legend, was killed by the Ancient Greek hero Jason and his intrepid Argonauts on their way through the Ljubljana marshes? 


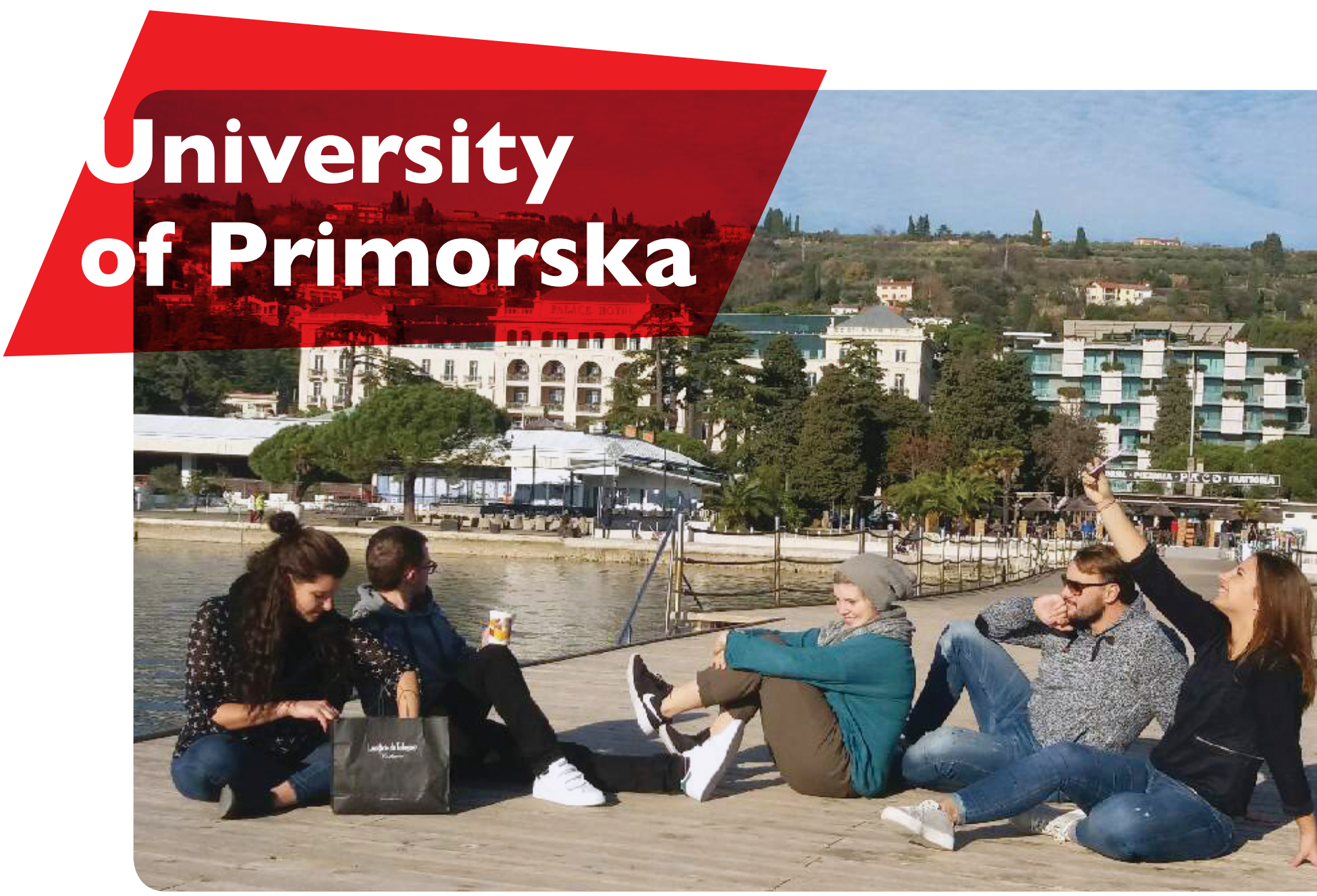

The University of Primorska is a public university that operates not only in a bilingual area, but also right at the spot, where three great cultures - Slavic, Roman and Germanic - meet. When strolling down the winding streets of our coastal towns, where our faculties are located, you will notice a number of historic monuments testifying to our rich intercultural past. Situated just a stone's throw from the sea, we have a wide horizon in front of us, literally and metaphorically. The sea implies lots of sun and a warm climate throughout the year, which means that you can take your laptops and books with you and find a sheltered nook to study somewhere outside our modern facilities. 
The University of Primorska was founded in 2003 and is today attended by more than 6000 students. The core values of the University of Primorska arise from the University's integration into the national area situated at the crossroads of historical, cultural, linguistic and global paths and its complete extroversion towards the world.
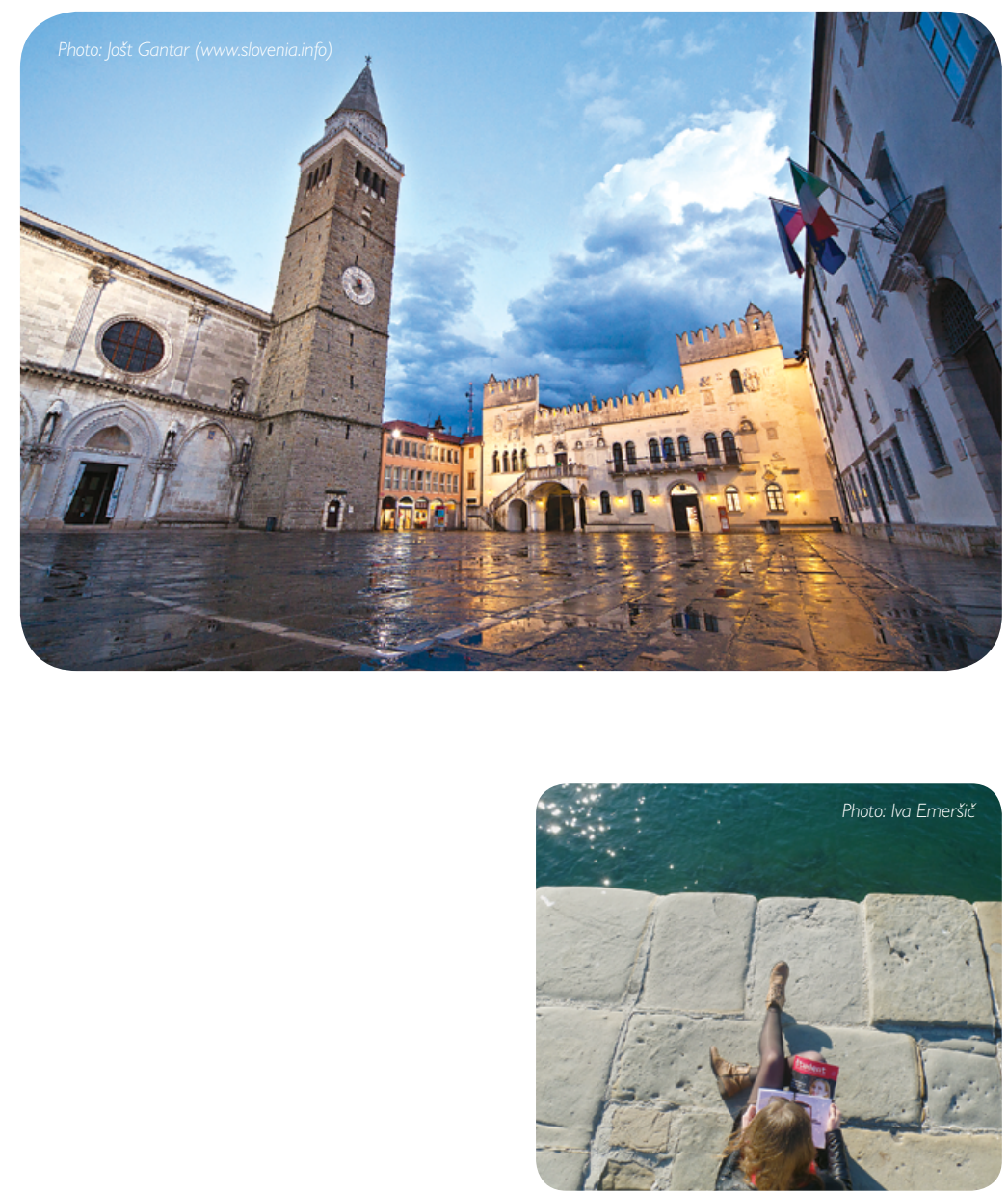

\section{THE UNIVERSITY OF PRIMORSKA HAS I I MEMBERS:}

Seven faculties:

- Faculty of Humanities

- Faculty of Management

- Faculty of Mathematics, Natural Sciences and Information Technologies

- Faculty of Education

- Faculty of Tourism Studies - Turistica

- Faculty of Health Sciences

- Faculty of Built Environment

A research institute:

\section{- Andrej Marušič Institute}

And:

\section{- Student Residences}

- University Library as well as two associate members:

- Faculty of Design Ljubljana - Valdoltra Orthopaedic Hospital 


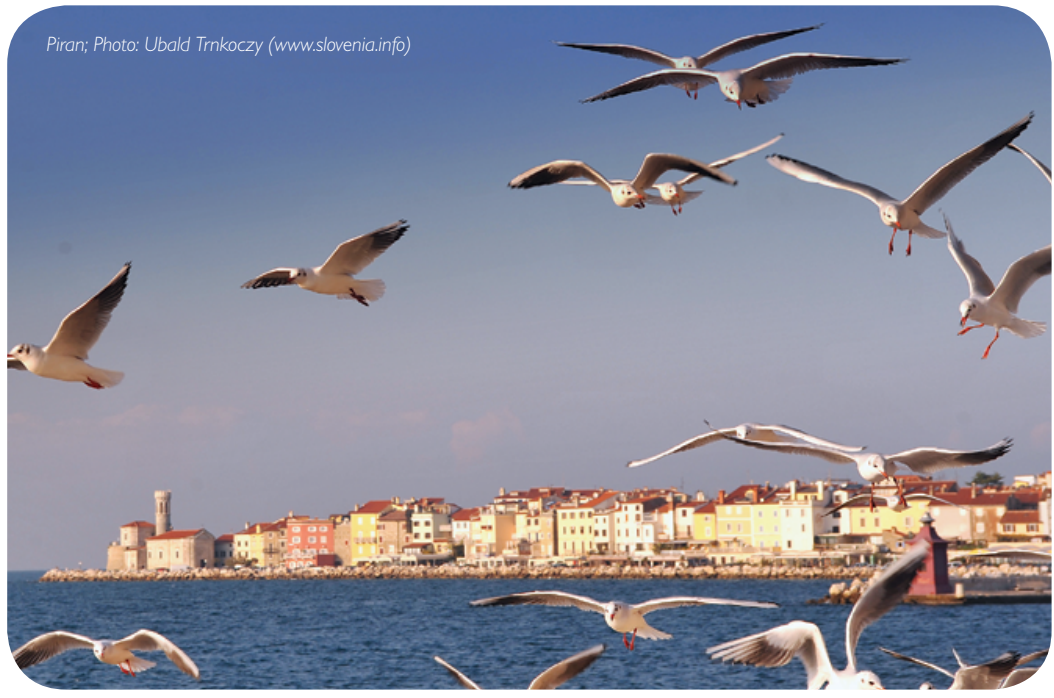

The old sea town of Piran has preserved the clustered medieval structure with narrow winding streets and houses, huddled close together, rising in cascades towards the ridge of the hill, which gives it a typical Mediterranean character. The city architecture was strongly influenced by the Venetian Republic, the strongest naval and commercial force in the Adriatic from the 10th century onwards.
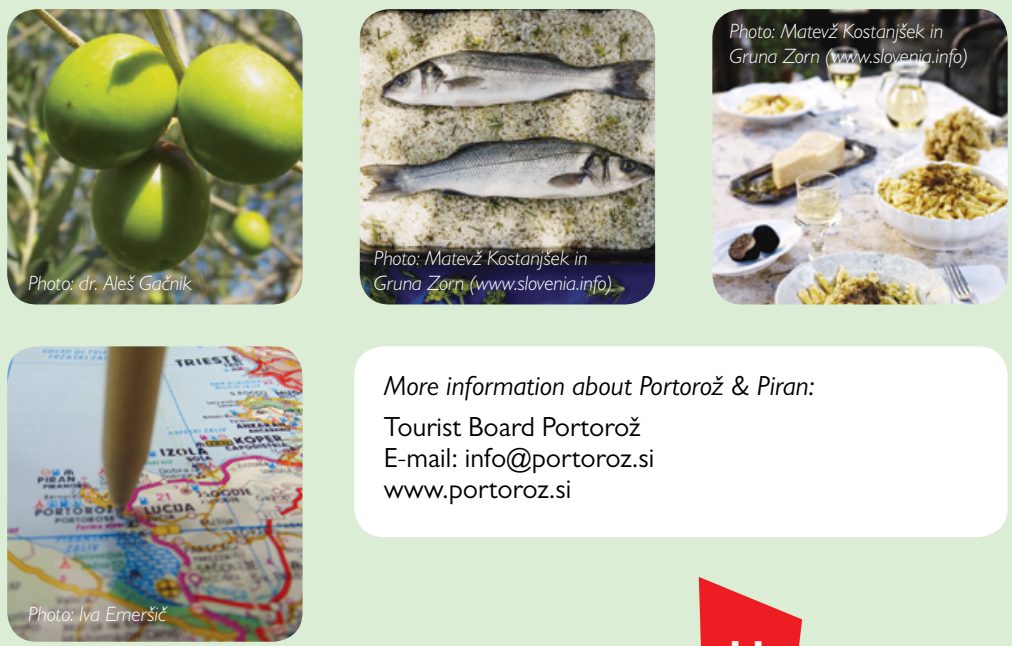

More information about Portorož \& Piran:

Tourist Board Portorož

E-mail: info@portoroz.si www.portoroz.si

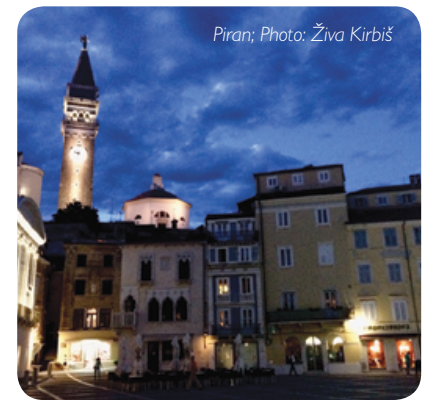

Piran; Photo: Živa Kirbiš

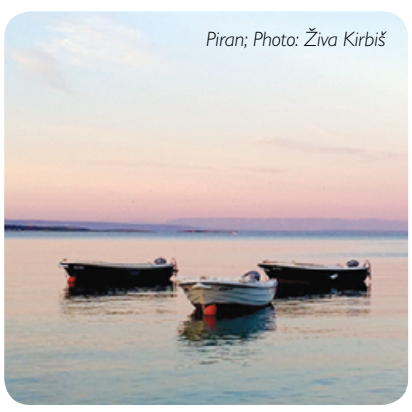

Today, the town of Piran together with Portorož, is an important tourist resort with numerous museums and galleries, hotels and restaurants, offering cultural events for any taste and attracting tourists with its picturesque geographical position and rich cultural heritage. It is also where the Faculty of Tourism Studies Turistica stands. Therefore students of Turistica have a great opportunity to study and gain priceless experiences in the socalled tourism laboratory. 


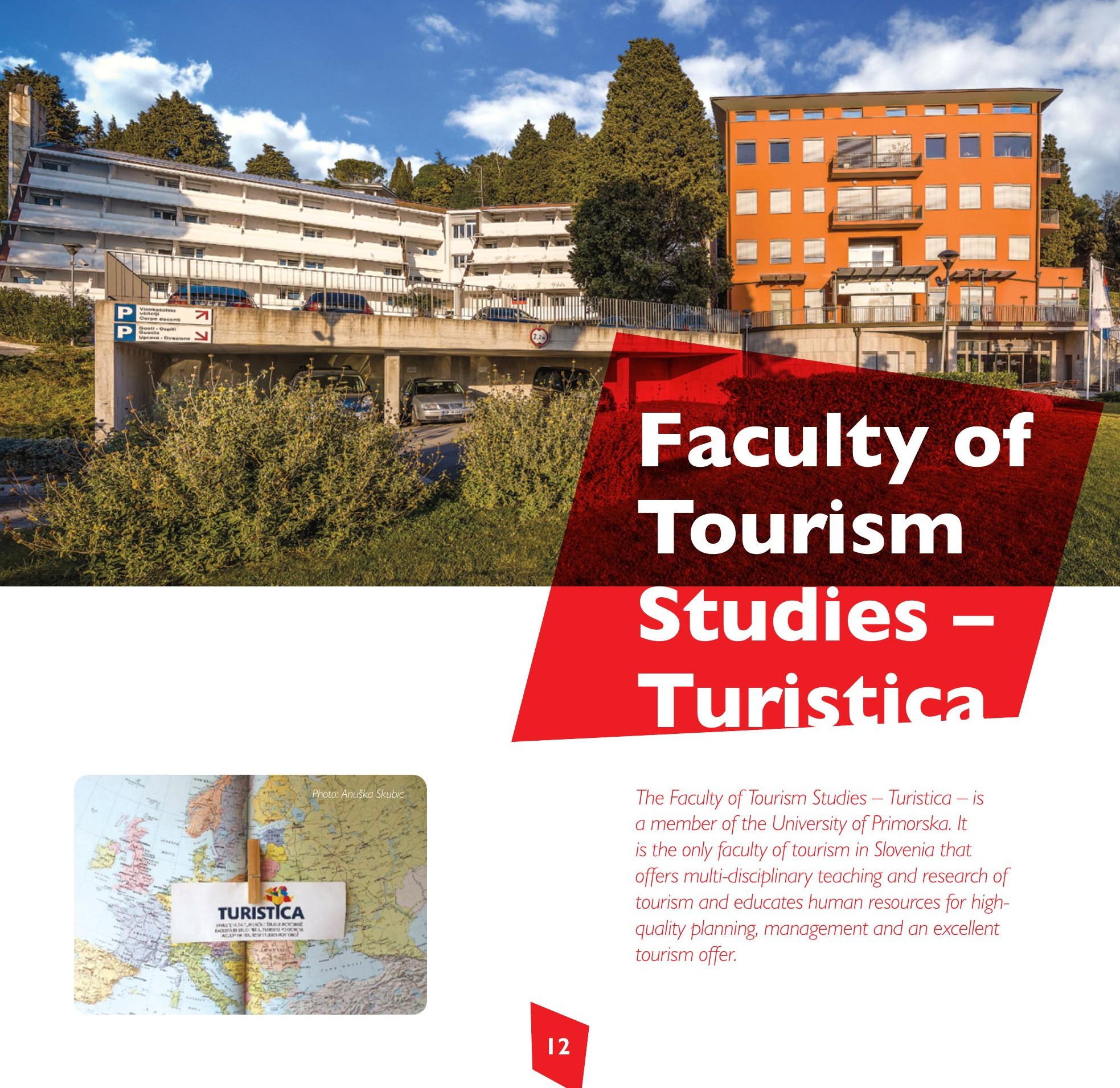


Univerza na Primorskem/University of Primorska

Fakulteta za turistične študije Turistica/Faculty of Tourism Studies Turistica

More information:
i www.turistica.si
( Obala I la, 6320 Portorož, Slovenia
f@UPFTSTuristica
@info@fts.upr.si
나 @ftsturistica

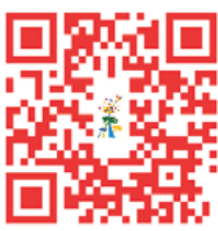

Turistica has its roots in the year 1994, when the College of Hotel and Travel Administration was founded in the frame of the Tempus project. A year later, the first generation of students enrolled. Since 2003, Turistica has been a member of the University of Primorska, and in 2008 it was transformed into a faculty.

Twenty years later, Turistica is proud to have study programmes on all three levels, as the doctoral study programme Innovative Tourism was implemented in 2012.

In addition to study activities, a wide range of other events takes place at Turistica, including the conferences Encuentros and TIM (Tourism, Education and Management), round tables FuTuristica, and the gallery AvanTuristica.

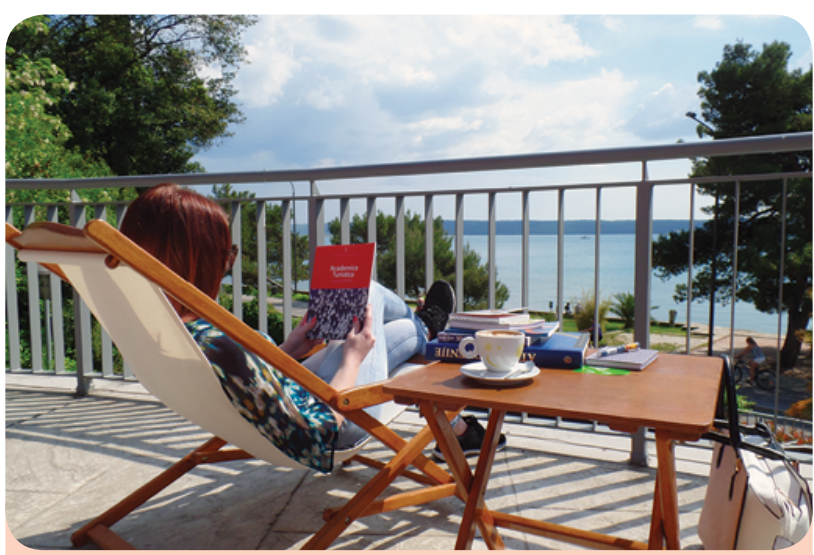

\section{THE MISSION STATEMENT}

Turistica creates and transmits knowledge for the sustainable development of tourism.

ENTER THE WORLD OF TOURISM THROUGH THE DOORS OF TURISTICA.

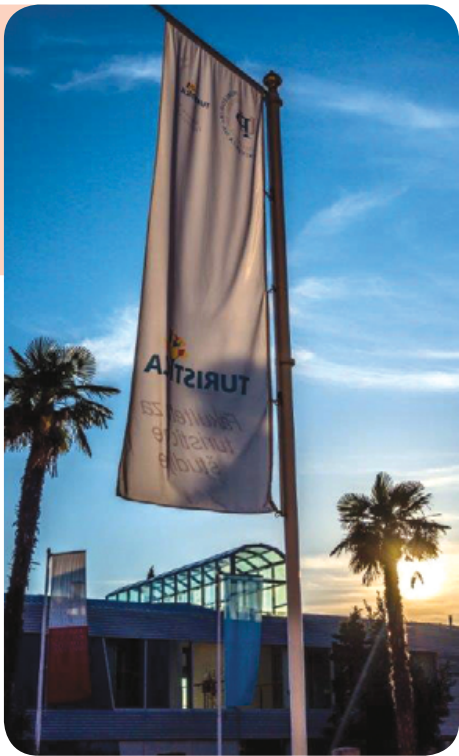


With more than 3000 graduates at the $\left.\right|^{\text {st }}$ level and more than 150 graduates at the $2^{\text {nd }}$ level!

More than 25 years of experience!

9 study programmes!

More than 80 research, developmental and market projects!

More than 50 publications on tourism!

Turistica is the only Slovene national higher education institution in the field of tourism offering bachelor (B.A.), master (MSc.) and doctoral (PhD) levels of study. Turistica is the only faculty in Slovenia in which tourism is being taught and researched with multidisciplinary approaches.

Bank of Tourism Potentials in Slovenia (BTPS), a project designed at Turistica, was rewarded by UNWTO with a prestige award for innovations in 2009.

In 2009 UNWTO awarded the library of Turistica with a status of a depository library of the World tourism organization.

In 20 I 4 the University of Primorska gained its prestigious membership in the UNESCO university network with the international operation of The Department for Cultural Tourism and Cultural Heritage at the Faculty of Tourism Studies - Turistica.

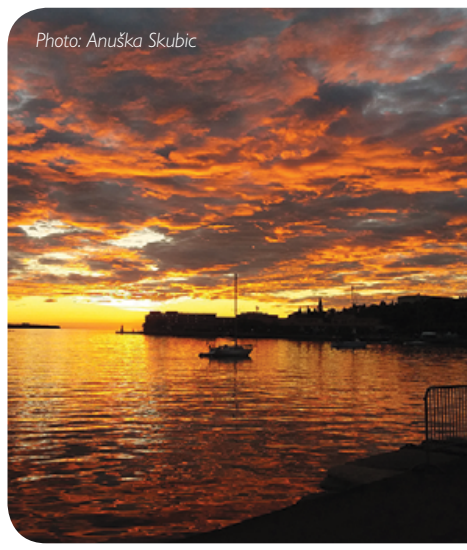




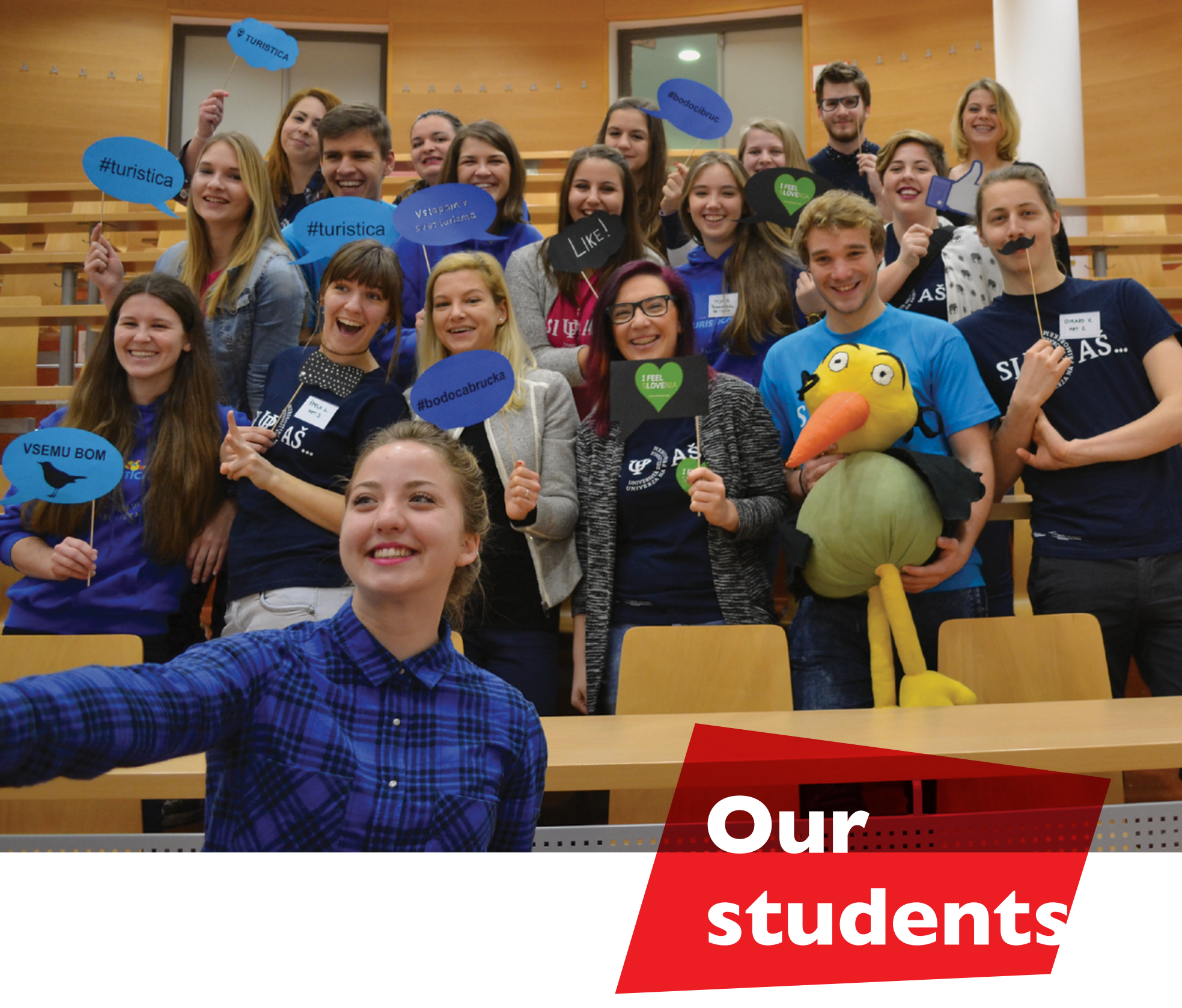




\section{FOREIGN STUDENTS ABOUT TURISTICA}

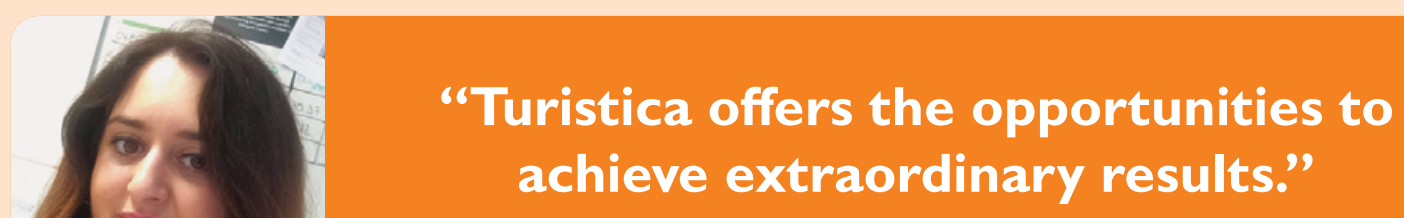

Nermina Vilić, Foreign student (Bosnia and Herzegovina)

"As a foreign student, I was attracted to Turistica because I knew it would offer the opportunity to work and interact with knowledgeable professors and brilliant students, and help me achieve my goal to become an expert in the field of tourism. Turistica offers many opportunities to expand talents in tourism business, to inspire and motivate others, and achieve extraordinary results. That is why, I highly recommend to study at Turistica. "

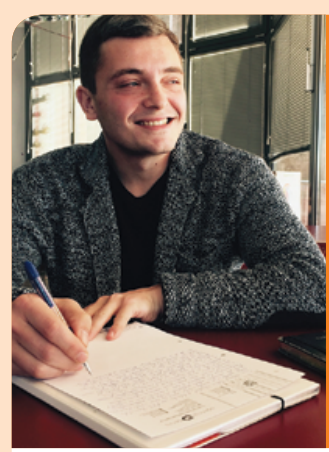

\section{"The faculty gave me a warm welcome and the people there have helped me through my studies and that has got me to where I am today"}

Marsel Valiev, Foreign student (Russia)

"I am now a third year student at Turistica and my story started in 2013, when I arrived to the Slovenian coast with my family to support my father at an Ex-tempore competition. I fell in love with Slovenia and promised myself that I would return some day. I applied to Turistica and I haven't felt any regret because the faculty gave me a warm welcome and the people here have helped me through my studies and that has got me to where I am today: being fluent in Slovene and soon completing my Bachelor's degree. To all the freshmen I would like to give a simple advice: follow your dreams, be independent and be devoted to what you want to do with your life. Keep it real and best of luck!'” 


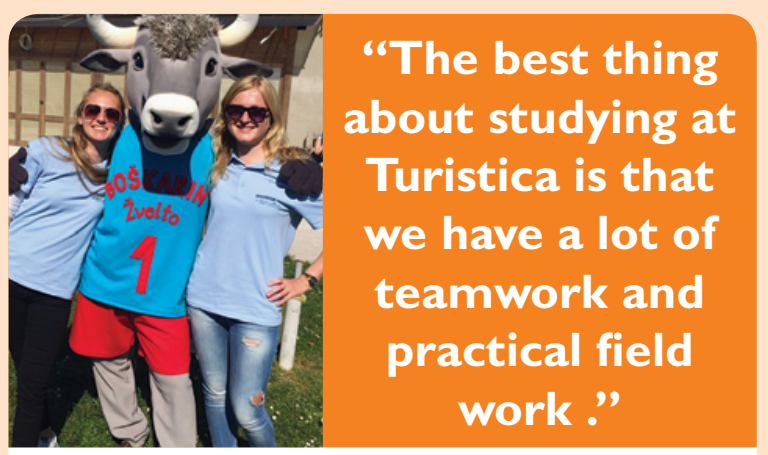

Anastacia Chemerys

Foreign student (Ukraine)

"I started my studies of hospitality and tourism in Ukraine, but when my mum moved to Slovenia, I decided to continue at Turistica. Immediately the faculty gave me the opportunity to attend a course of Slovenian language, which helped me a lot, and now, after a year and a half, I am fluent in Slovenian. The best thing about studying at Turistica is that we have a lot of teamwork and also practical work. Students study very seriously, but despite this, the student life on the coast is really nice. I like the fact that students tend to get together also outside class and study hours. Since Slovenia is a small country, you can travel around it in one day and get to know its heritage and culture. Due to the central location of the country, I often visit the neighbouring countries with my friends, we also frequently visit the nearby cities of Trieste and Venice.

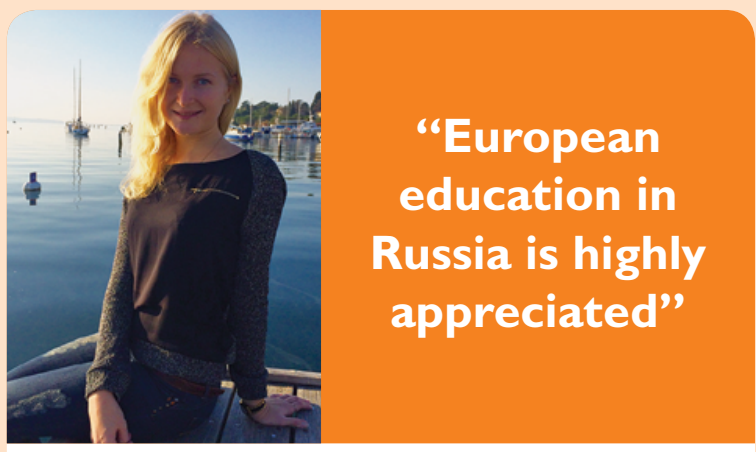

Tatyana Makarova,

Foreign student (Russia)

"I decided to study in Slovenia because European education is highly appreciated in Russia. I am strongly interested in tourism, as I like working with people in a dynamic environment. I learned the Slovenian language very quickly. Despite the fact that it is necessary to study a lot, I like Turistica because we have a lot of field work and field trips, intercultural evenings and also some student parties. I find the Slovenian habit of socializing over a cup of coffee really interesting. Another thing that surprises me is that Slovenians do a lot of sport activities. Since flights are very affordable, because of the nearby Italian airports, I have so far travelled to many European countries, but many times me and my friends visit the neighboring Croatia."

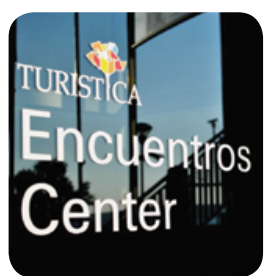

Turistica is engaged in international mobility of students and teachers and has implemented co-operation in research and study with universities and colleges inside and outside the EU, in particular in the Mediterranean area and the USA. Diverse international and professional events are organised - like FuTuristica, the bi-annually organized international meeting of researchers and teachers in tourism, or TIM - Tourism, Education and Management and Encuentros, which discuss current subjects in the field of tourism with numerous home and foreign experts. 


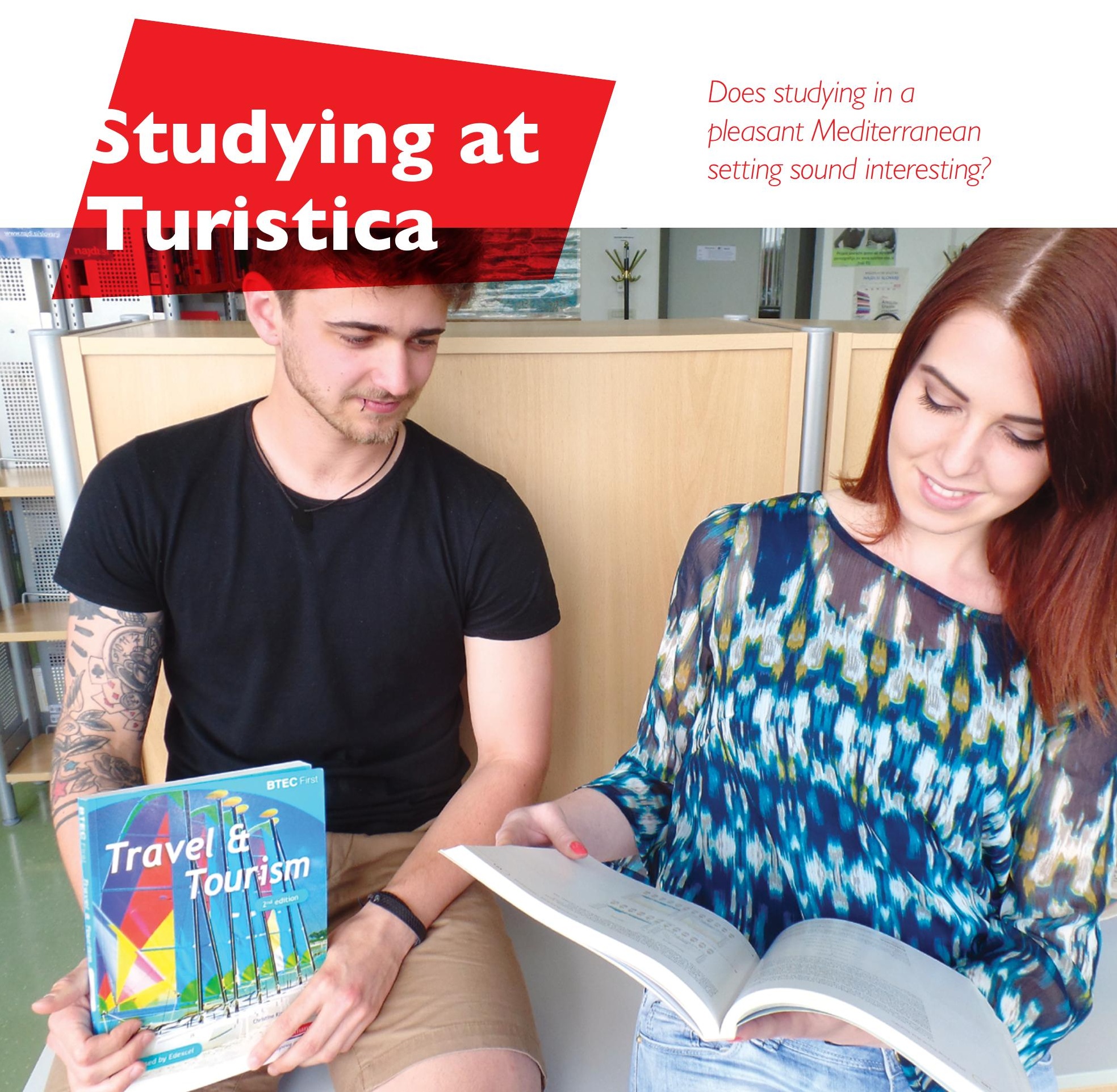



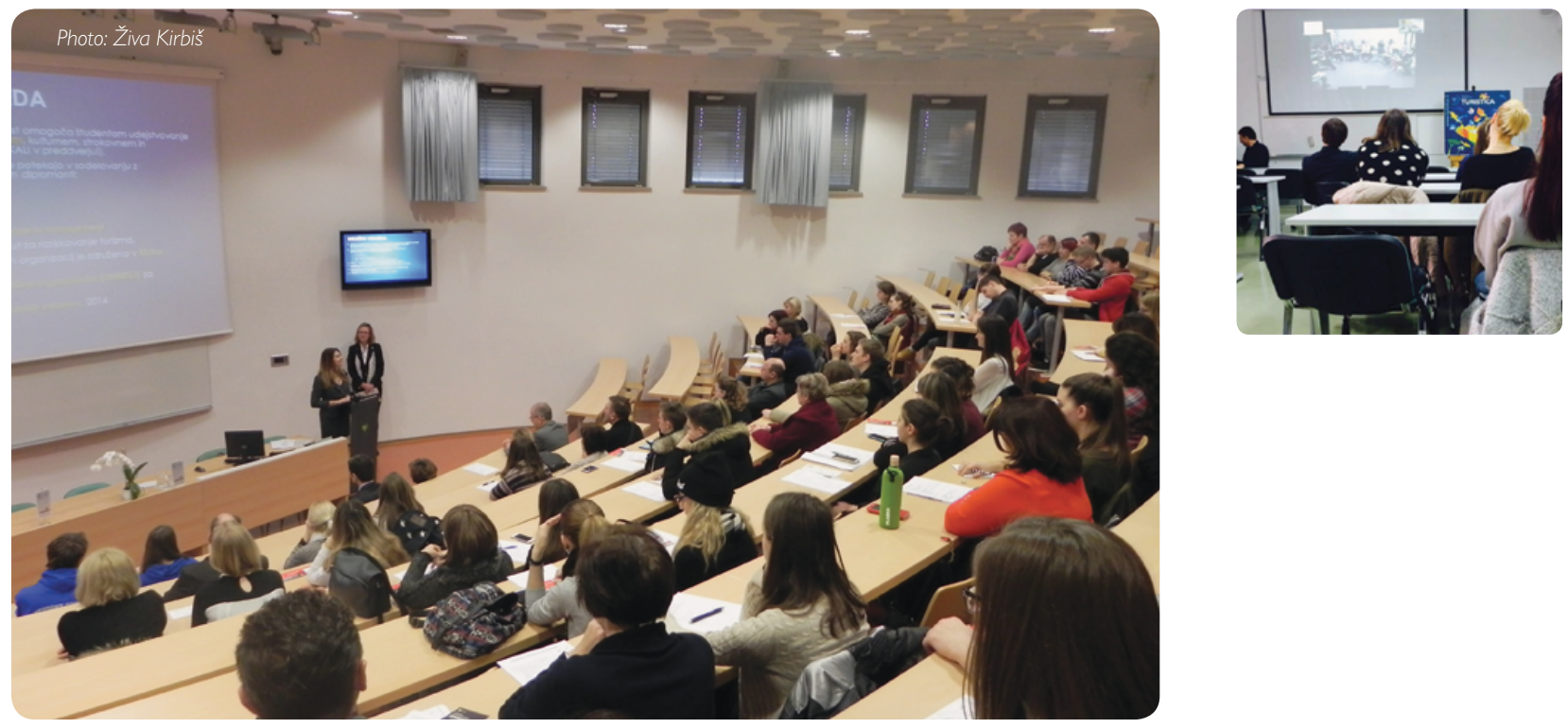

Turistica offers a wide range of modern and creative teaching methods, such as:

- video conference lectures with IUPUI Indianapolis University, USA

- tutorials, problem based learning, e-learning, design thinking

- field work, case studies, research workshops, excursions

- visiting tourism events and exhibitions

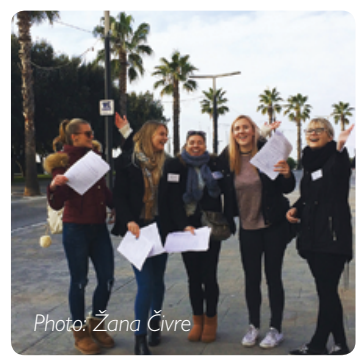

- outstanding number of guest lectures

- study visits at Slovenian tourist companies

- international summer schools and conferences

- volunteering in sport, cultural and eco events

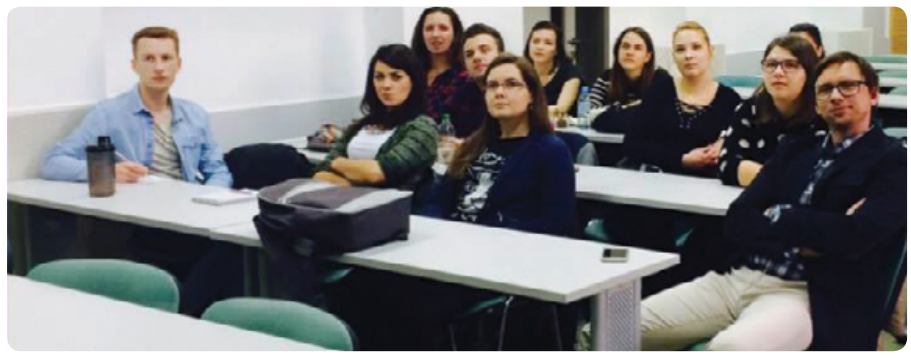



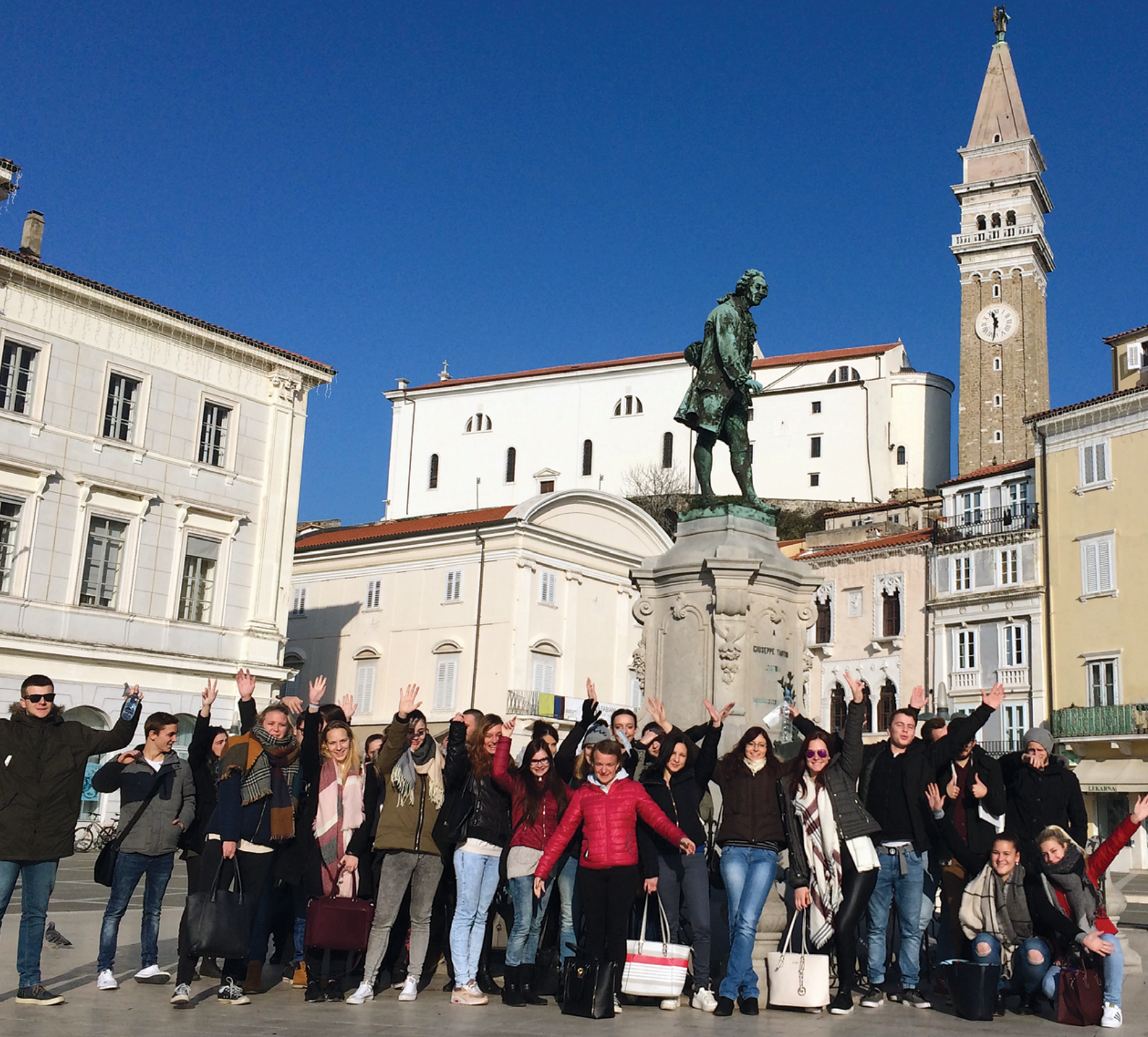


\section{VISITING LECTURES}

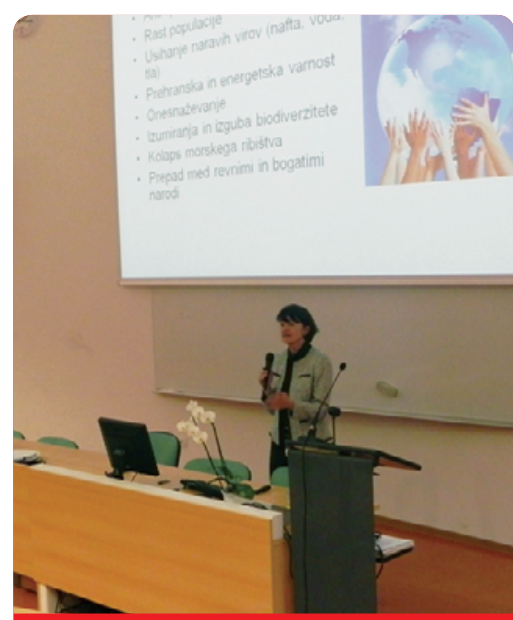

Prof. dr. Lučka Kajfež Bogataj, Nobel Peace Prize winner (2007) as a member of Intergovernmental Panel on Climate Change (IPCC) awarded jointly with Albert Arnold (Al) Gore Jr. "for their efforts to build up and disseminate greater knowledge about man-made climate change, and to lay the foundations for the measures that are needed to counteract such change". (www.nobelprize.org)

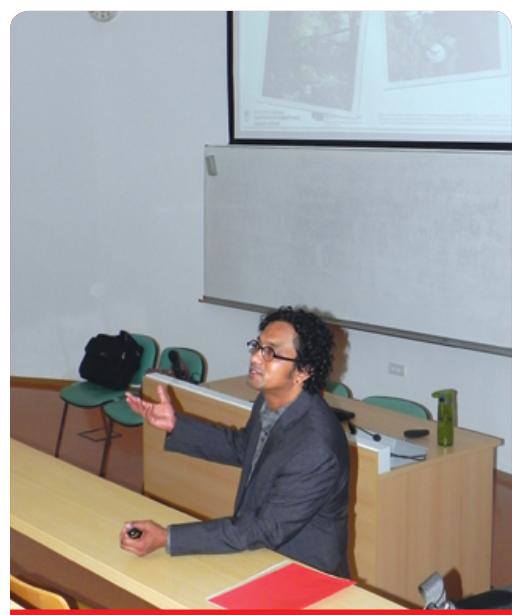

Visiting lecture by Ass. Prof. Vinod Sasidharan, Ph.D. from San Diego State University, United States of America, Turistica's partner university for mobility.

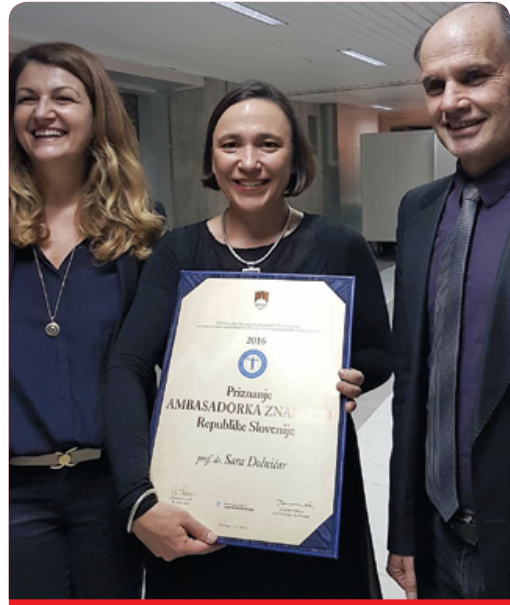

Prof. dr. Sara Dolničar researches at The University of Queensland in Australia. Since 2012 she has been cooperating with Turistica, especially on the doctoral program Innovative tourism at Turistica. Prof. dr. Sara Dolničar received a prestigious Ambassador of Science award, recognised by the Republic of Slovenia for her outstanding research achievements in marketing and tourism. Globally she ranks among the $2 \%$ of the most successful researchers in the wider field of marketing. 
Name of programme:

\section{Cultural tourism}

Level of study programme:

I

Type of study programme:

\section{university}

Duration (in years and ECTS):

3 years (six semesters), 180 ECTS

Degree awarded:

diplomirani organizator turizma, equivalent to Bachelor of Tourism (B.S.)

\section{CULTURAL TOURISM}

Graduates of the first level university study programme Cultural tourism become experts with theoretical and practical knowledge for managing tourism and cultural organizations. Graduates will know how to connect tourism services with the dimensions of heritage and contemporary creativity on the regional, national as well as international level.With that they may contribute to the protection, promotion and development of local specialties as a base of contemporary tourism offer. They are capable of taking over the tasks in researching, analyzing, planning, shaping, developing processes in tourism business in connection with culture on the level of economic as well as public, non-governmental and cultural organizations. Their skills enable graduates in Cultural tourism to be employed in organizational institutions (travels, events, festivals), in museums and galleries, in promotions as well as in the media, as culture and tourism specialized journalists. 
Name of programme:

Tourism destination management

Level of study programme:

I

Type of study programme:

Higher education professional programme

Duration (in years and ECTS):

3 years (six semesters), I 80 ECTS

Degree awarded:

diplomirani organizator turizma, equivalent to Bachelor of Tourism destination management (B.S.)

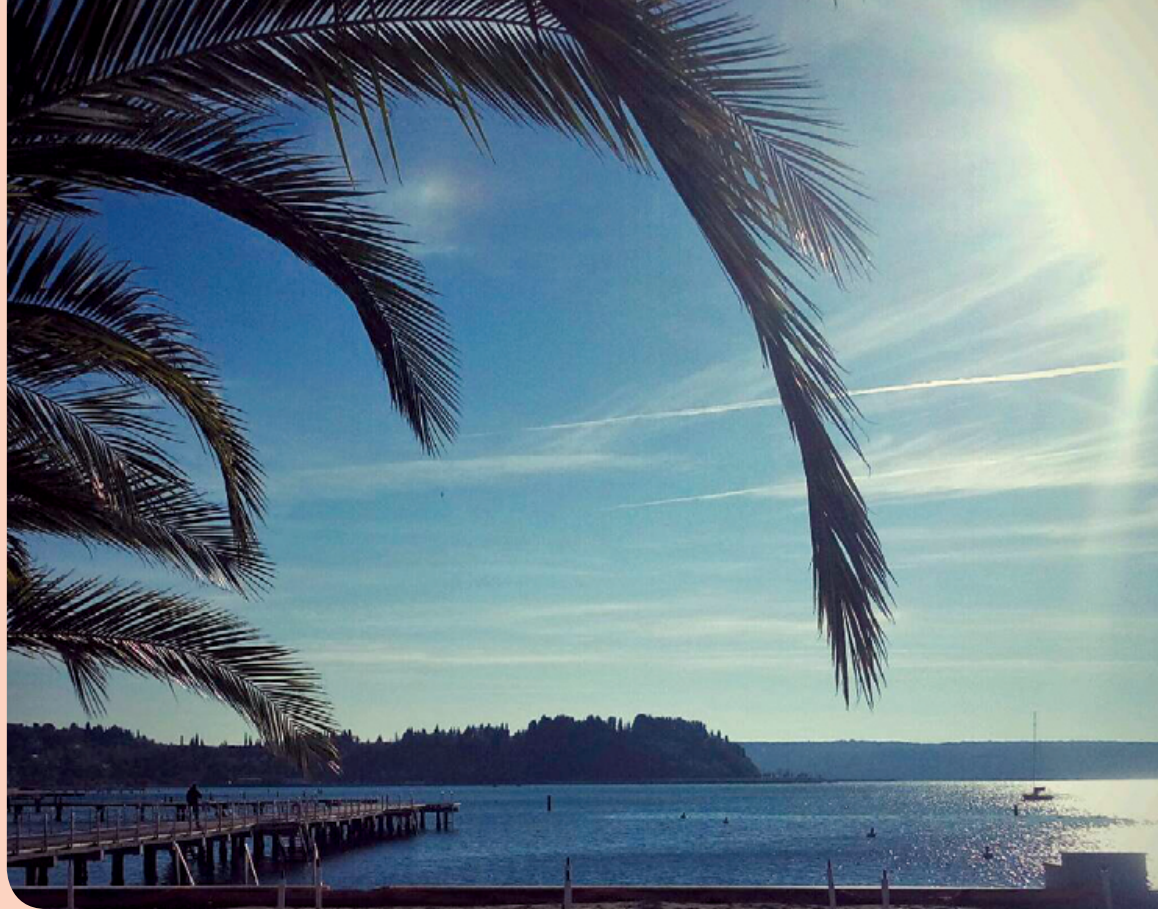

We also offer two undergraduate professional programmes:

\section{TOURISM DESTINATION MANAGEMENT}

Graduate of the study programme of the first level Tourism destination management are an expert in theoretical and practical knowledge for managing tourism organizations, managing complex processes in the field of tourism, methodological research knowledge, with which they can independently carry out research and are qualified for the management and implementation of professional tasks that fall within the scope of tourism services. At the same time, graduates are able to successfully enrich tourist services with cultural traditions of our society and environment. Graduates are able to work both at the level of business as well as public organizations as in travel agencies, local, regional and national tourist organizations, tourist information offices, agencies and as representatives in foreign tourism markets. 
Name of programme:

Tourism Enterprise Management

Level of study programme:

I

Type of study programme:

Higher education professional programme

Duration (in years and ECTS):

3 years (six semesters), 180 ECTS

Degree awarded:

diplomirani organizator turizma, equivalent to Bachelor of Tourism

Enterprise Management (B.S.)

\section{TOURISM ENTERPRISE MANAGEMENT}

Graduates of Tourism enterprise management understand the dynamics of domestic and international tourism markets, marketing activities in the tourism sector, and particularly, business, organization and management of business systems in tourism. The knowledge of operational and technological processes in tourism companies, relevant knowledge in economics and business management, knowledge of creating integral tourist products of destinations and knowledge of the language enable graduates to be important contributors in the tourism industry. Hence, they are indispensable in the development of tourism products and their marketing as well as in conducting business systems in tourism by working as experts in tourist accommodation establishments and in complementary tourist activities (ex. congresses, gaming, spa) as well as in tourist agencies.

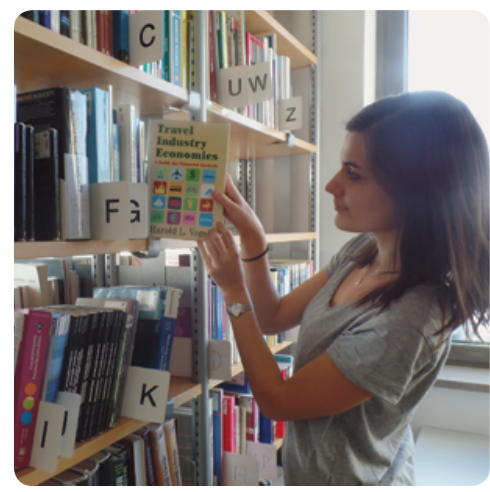




\section{Are you thinking}

\section{about continuing your studies?}

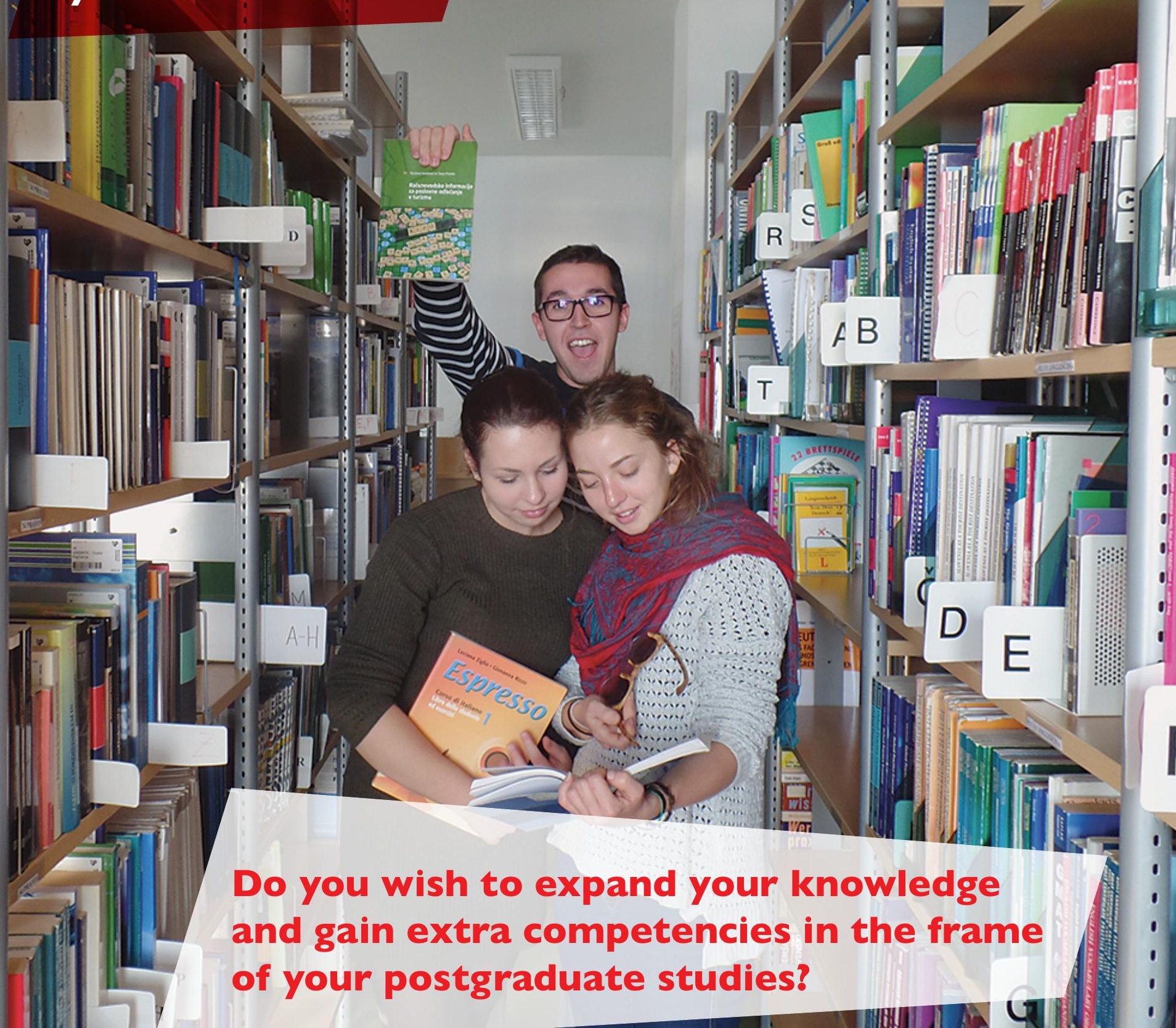




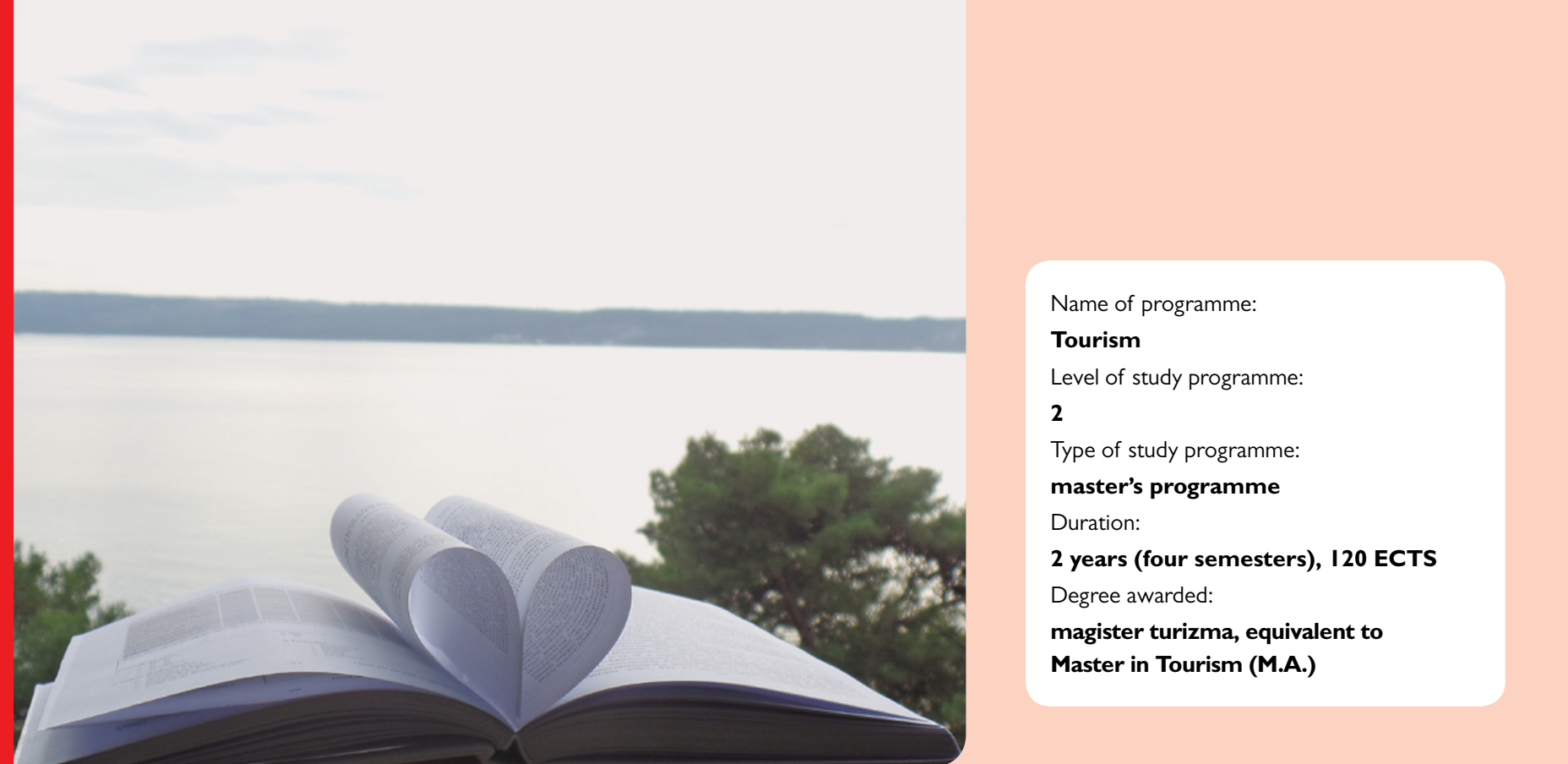

\section{UP FTŠ Turistica offers three 2nd level study programmes:}

\section{TOURISM}

The postgraduate study program of Tourism is interdisciplinary and looks upon the phenomena of tourism from socio-cultural, economic and business, environmental, science and research perspectives. Students develop the ability to shape new concepts and models of tourism, tourism products and services development. It offers the possibility to choose between two directions: businessorganizational or social-environmental. Students are given the opportunity to conduct researches in tourism individually. They recognize trends and factors of influence, understand the functioning of tourism subjects, connect various perspectives of tourism development (social, personal, environmental, macroeconomic and enterprising factors) and are able to make decisions according to their understanding of this complex mechanism. Graduates of the Tourism program can work as managers in tourism economy in private or public sectors. 
Name of programme:

\section{Heritage tourism}

Level of study programme:

2

Type of study programme:

\section{master's programme}

Duration:

2 years (four semesters), I 20 ECTS

Degree awarded:

magister dediščinskega turizma, equivalent to Master of Heritage Tourism (M.A.)

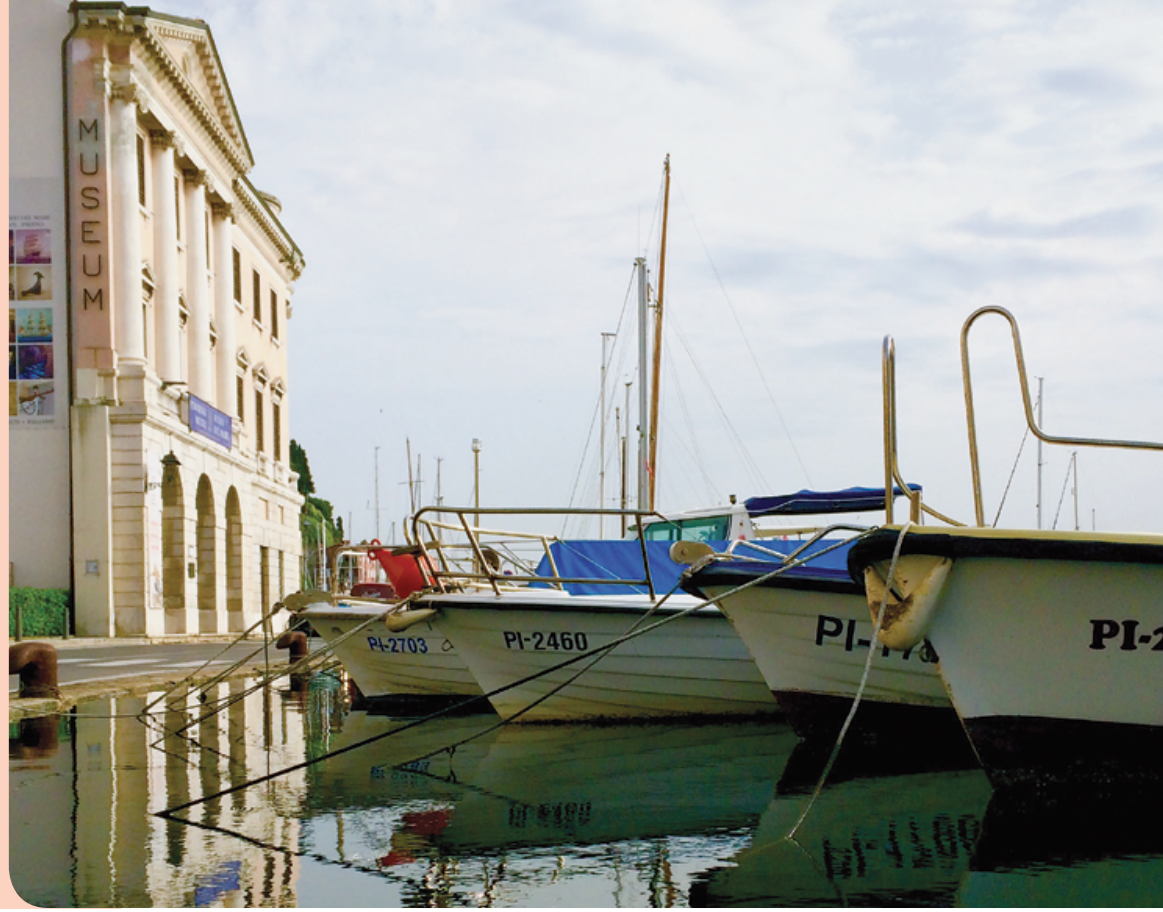

\section{HERITAGE TOURISM}

(* in cooperation with UP Faculty of Humanities)

The study programme aims to incorporate natural and cultural resources into the Slovenian and foreign supply of tourism products. This is the first study program which aim is to disseminate knowledge of heritage into the sphere of tourism. Both aspects exist as individual professional branches and have not yet been intertwined in a study program before. Heritage Tourism studies combines knowledge and competencies from the fields of cultural and natural heritage with the know-how of tourism management. The applied aspect of understanding the importance of heritage in tourism comes in the foreground of discussion. Students gain knowledge filled with creative work in a prosperous branch of economy. The goal of the study program is to form a profile of professionals - Master of Science graduates - for the tourism industry in general and specifically for their own business activities in tourism. This is an interdisciplinary study program, enrolment is open to students with an undergraduate degree (3 years) in the fields of humanities, tourism, natural and cultural sciences as well as from other study environments. The heritage tourism experts can work as highly specialized experts in tourist organizations, environmental organizations, public and private sector, etc.. 
We also offer the 3rd level study programme:

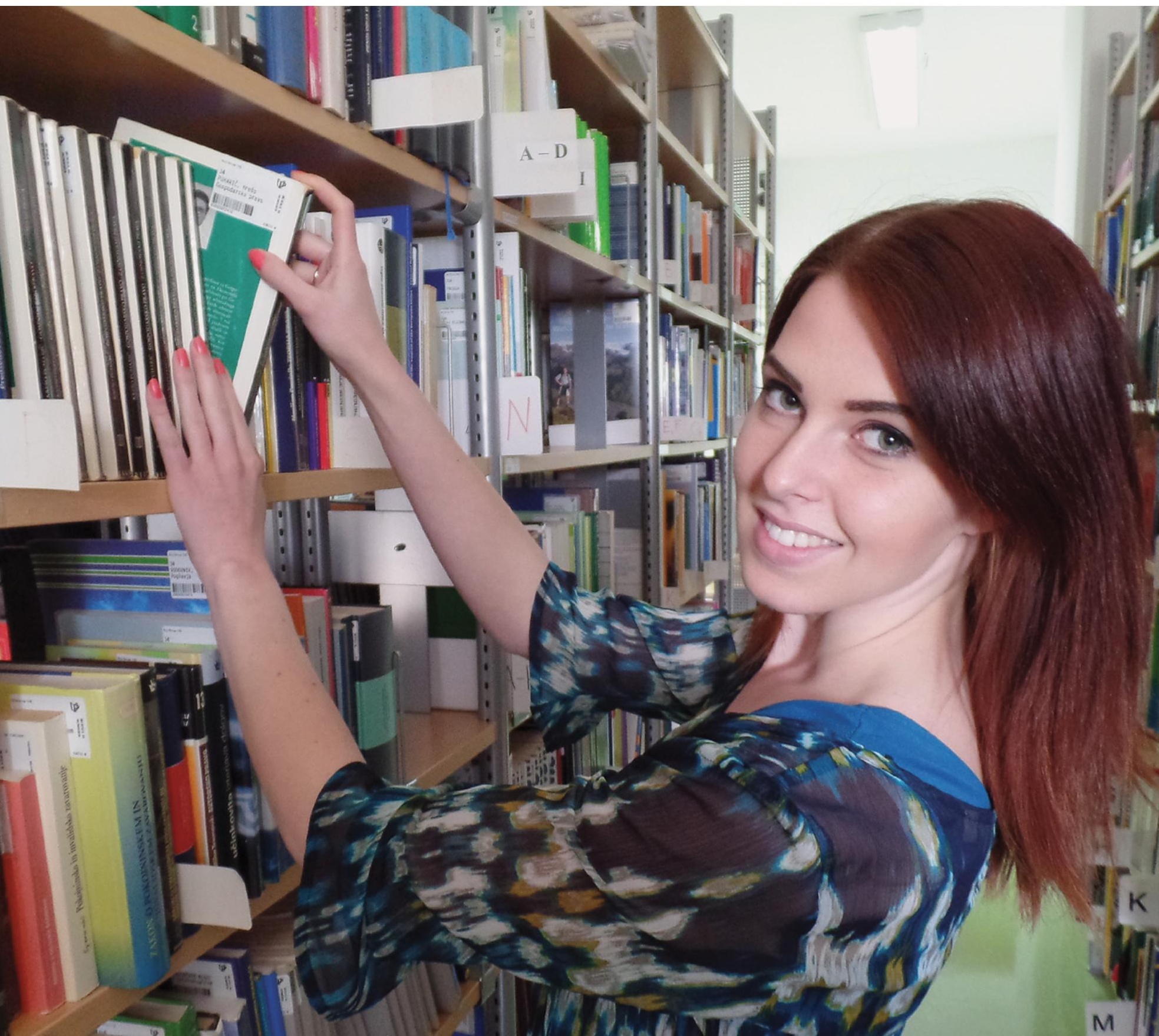




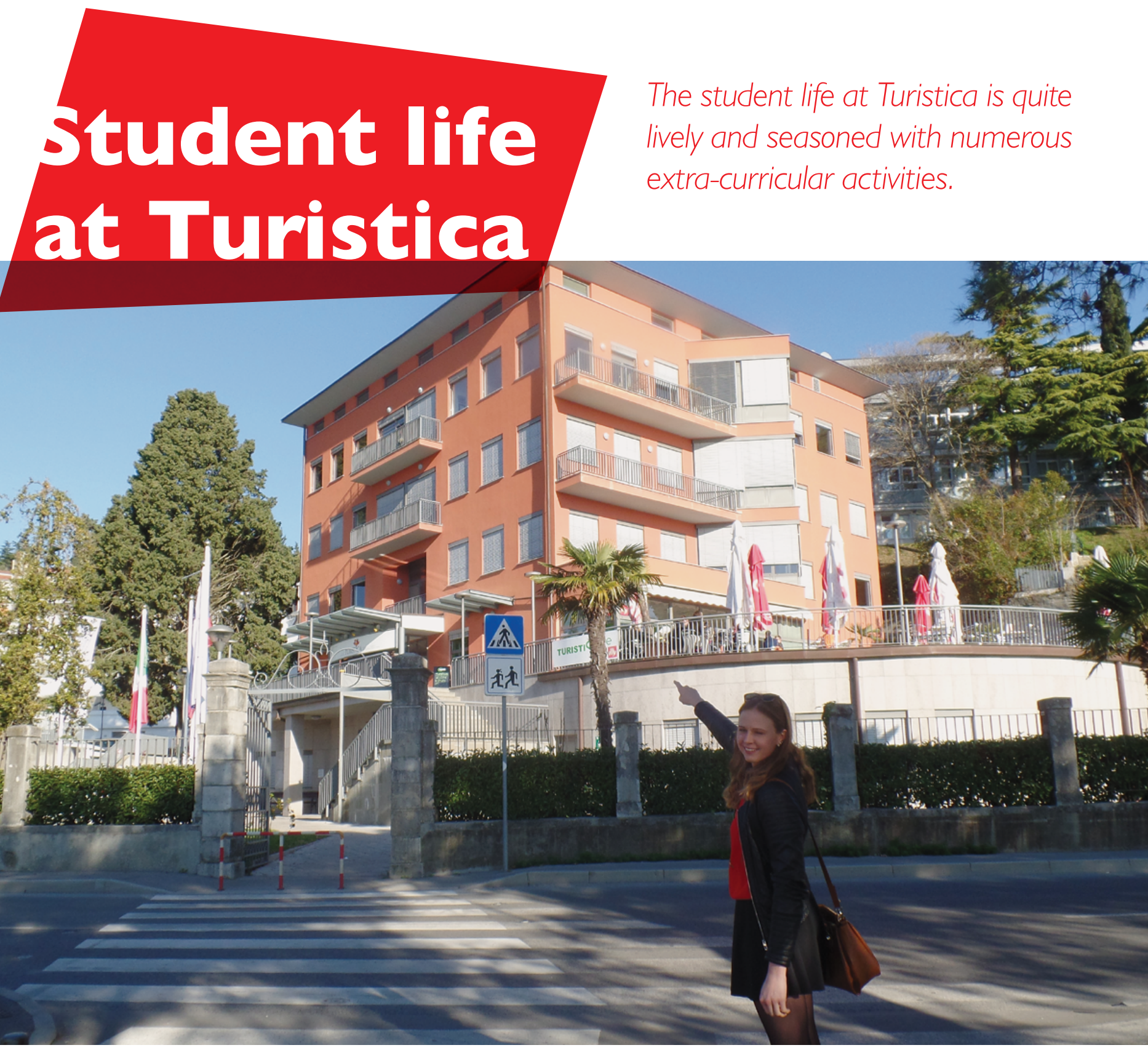


Social events are organised by the Student Council of UP FTŠ Turistica: Freshmen party, Turizmijada (International congress for tourism students from the Balkan region), Mind the Gap excursion to London, Summer schools, ITB Berlin, professional excursions to Slovenia and abroad, EIAT Belgrade (Serbia), The International Congress of Students of Tourism and Hospitality in Novi Sad (Serbia), competitions in the frame of the University League (basketball, soccer, volleyball) and the Women's rowing team.

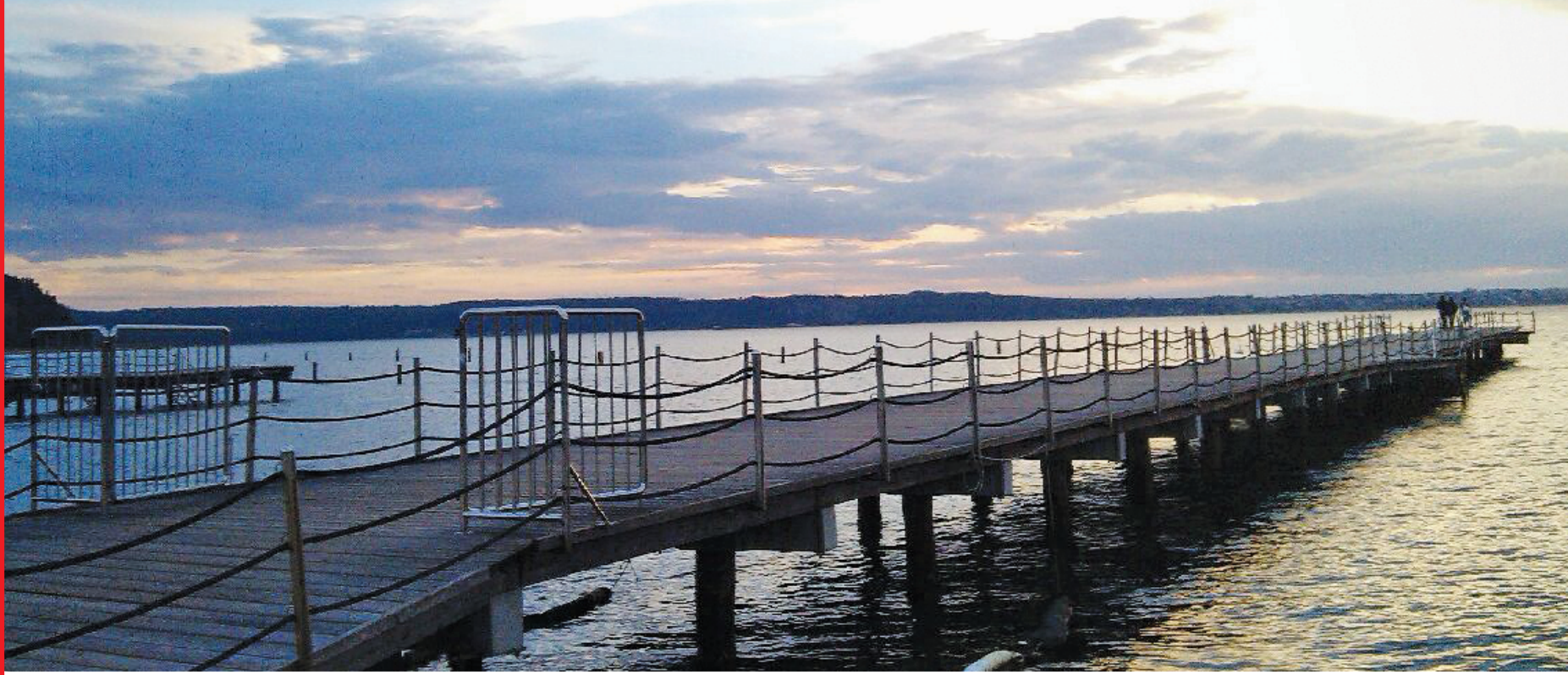

The faculty also hosts cultural events, like International evenings, and a theatrical group ArtTur. It as well publishes a student journal Flaneur.

Your studies will take place in the pleasant Mediterranean environment, where tourism represents everyday life and in this way, you will experience the beat of Portorož. 


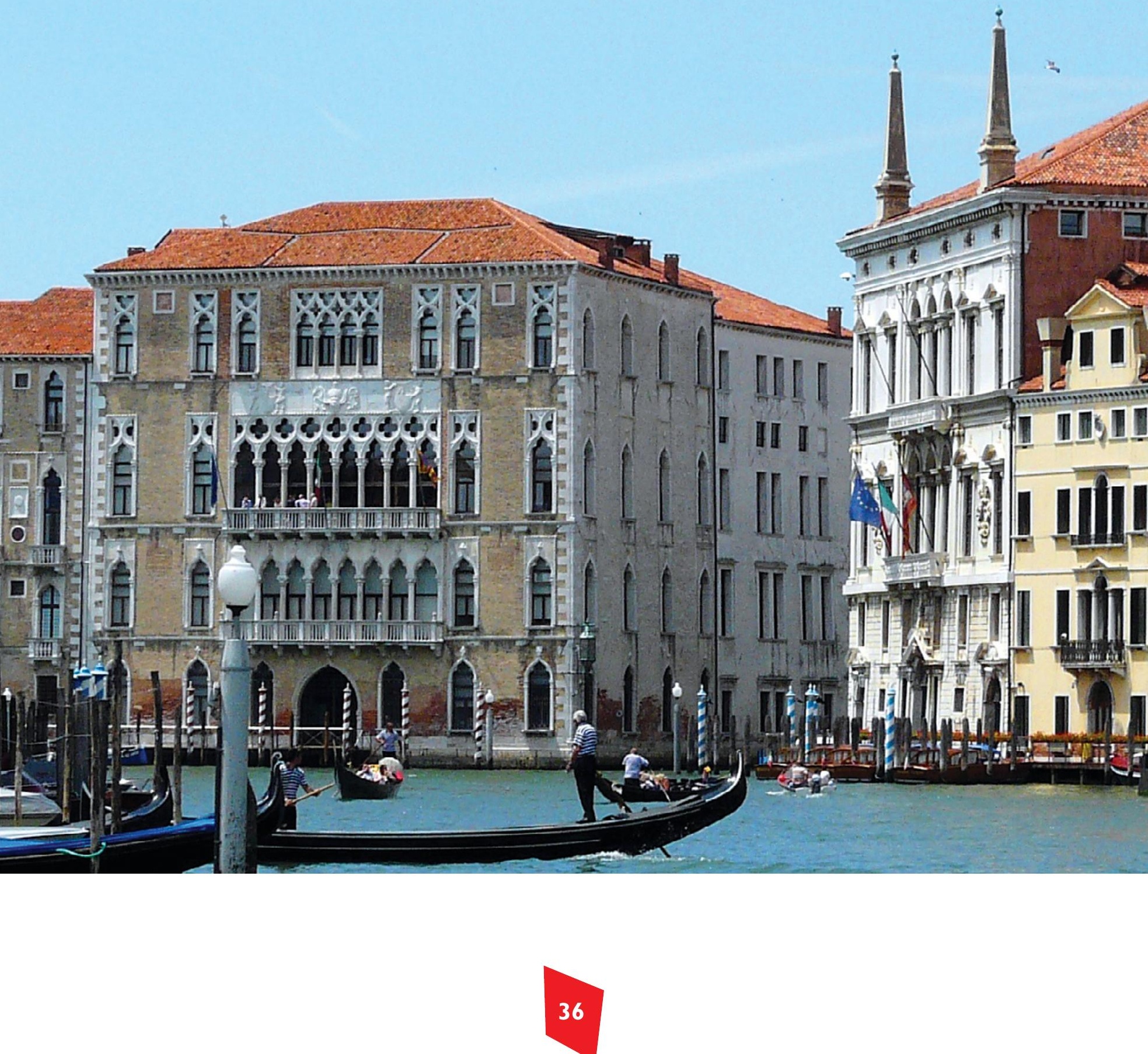



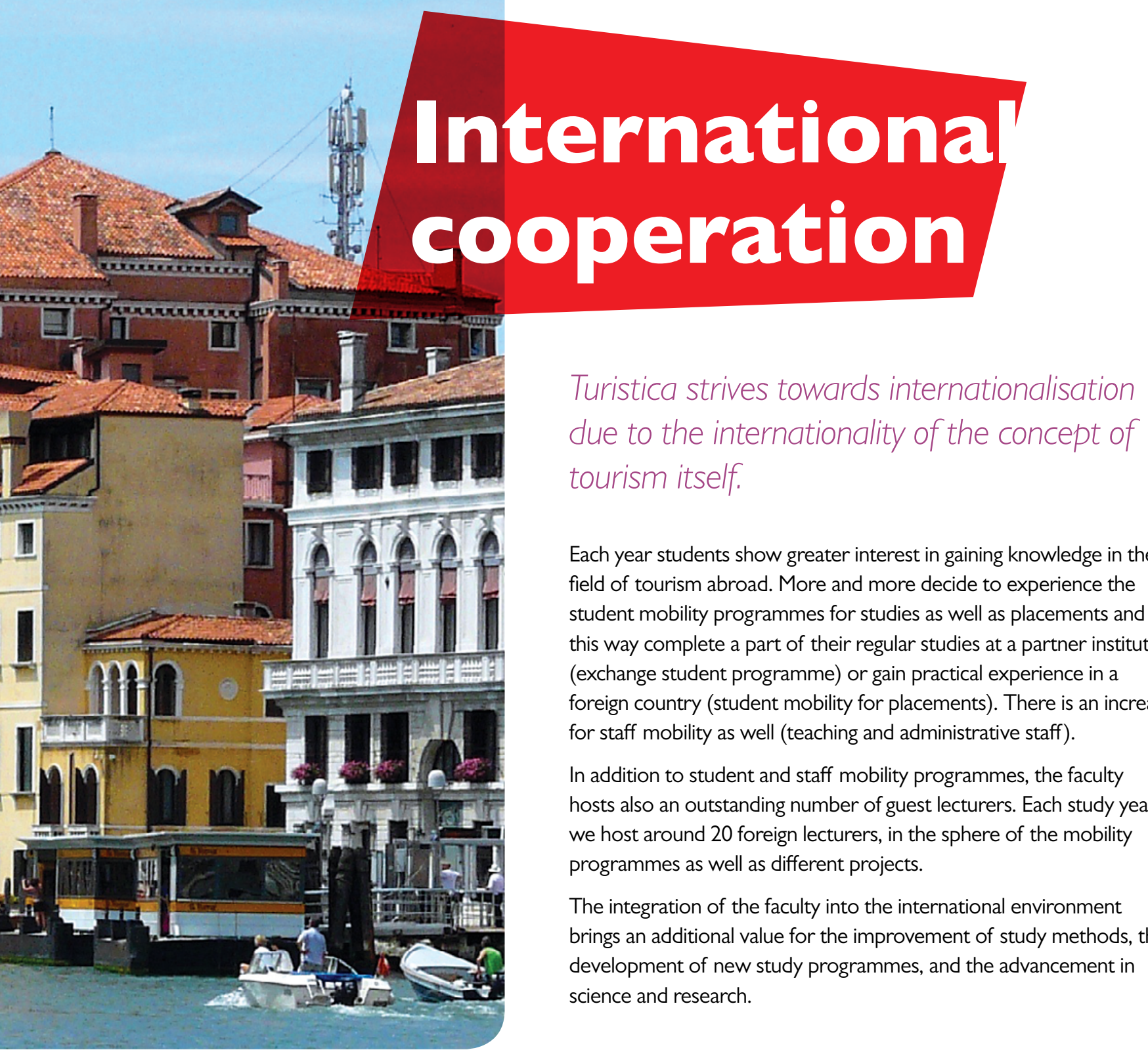

Each year students show greater interest in gaining knowledge in the field of tourism abroad. More and more decide to experience the student mobility programmes for studies as well as placements and in this way complete a part of their regular studies at a partner institution (exchange student programme) or gain practical experience in a foreign country (student mobility for placements). There is an increase for staff mobility as well (teaching and administrative staff).

In addition to student and staff mobility programmes, the faculty hosts also an outstanding number of guest lecturers. Each study year we host around 20 foreign lecturers, in the sphere of the mobility programmes as well as different projects.

The integration of the faculty into the international environment brings an additional value for the improvement of study methods, the development of new study programmes, and the advancement in science and research. 


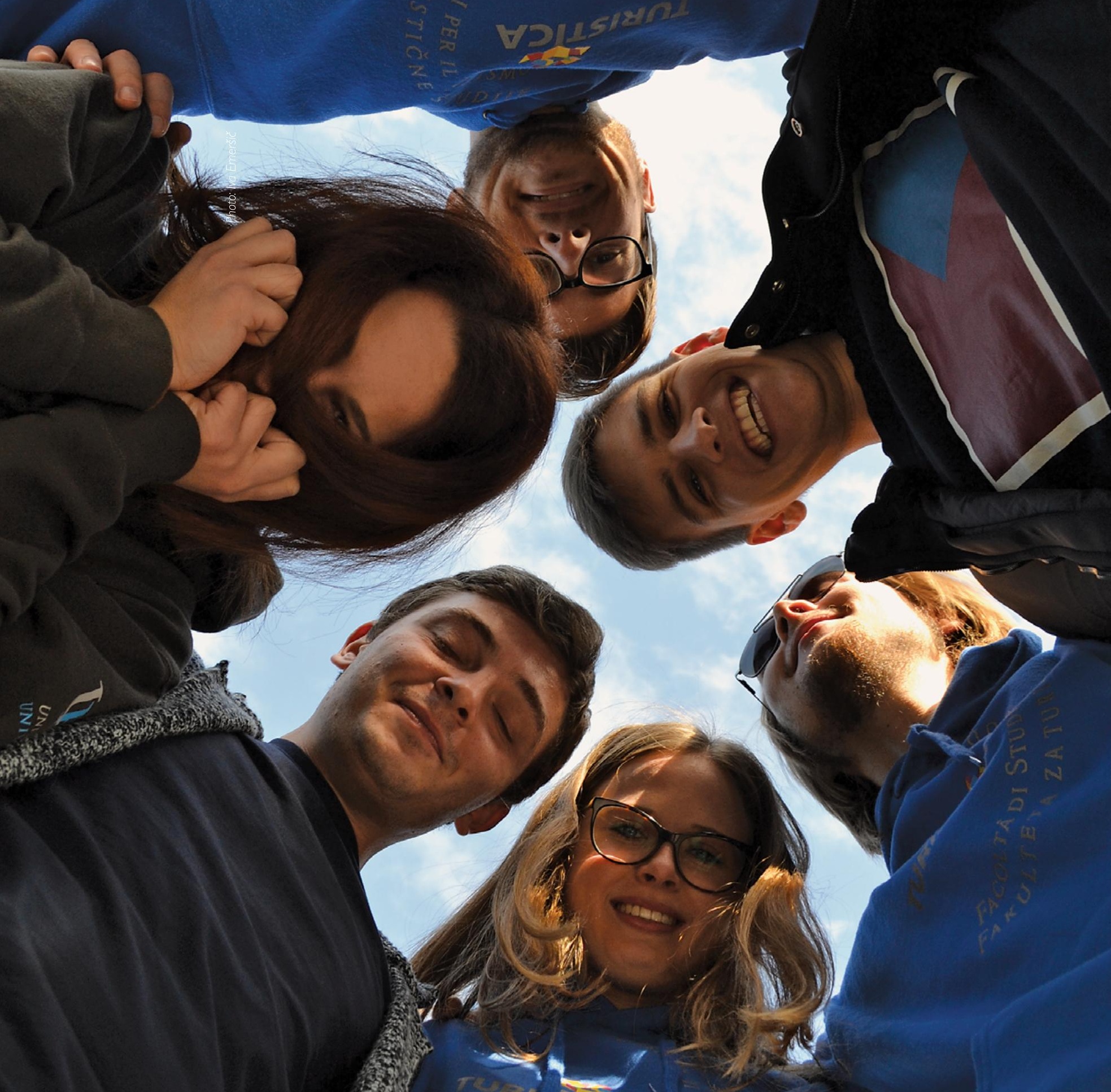




\section{EXCHANGE PROGRAMMES - A PRICELESS OPPORTUNITY FOR STUDENTS}

Facts about the student exchanges at Turistica:

More than 100 students participated in the Erasmus+, Ceepus, EGP/NFM and other exchange programmes;

Most students (60\%) decide for the study mobility;

Most of the exchanges are in the frame of the Erasmus+ programme (86 \%); and here $70 \%$ are mobilities for study and $30 \%$ for placements;

Approx. $92 \%$ of all mobilities are performed by undergraduate students;

$84 \%$ of mobilities are carried out by female students;

The TOP destination for students of Turistica is Spain. It is especially interesting for practical experience, and it is followed by the Czech Republic, Austria, the Netherlands and Germany;

The average duration of mobilities is 4.5 months. 


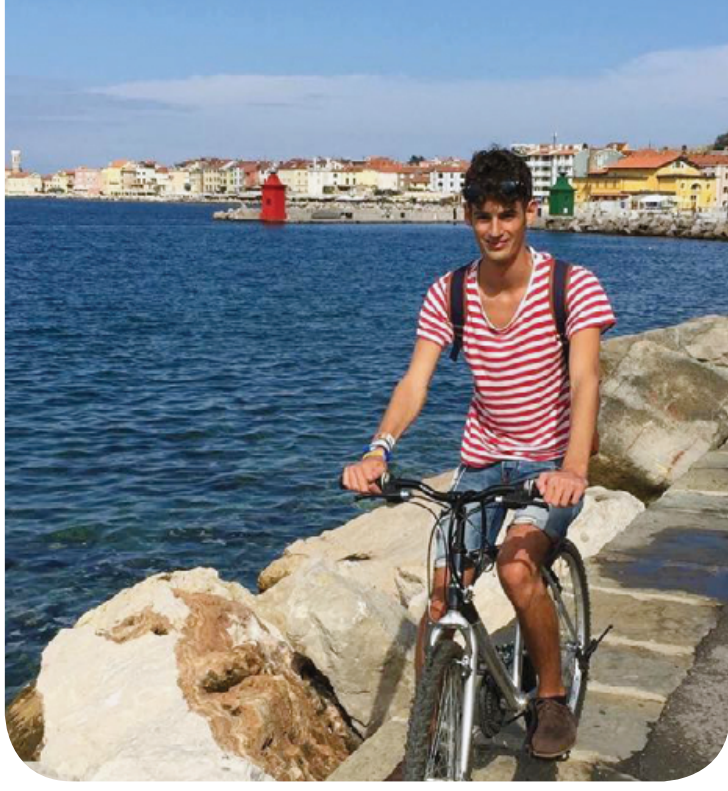

"I have many memorable moments of my Erasmus exchange at Turistica. What I liked the most about studying at Turistica is that we did a lot of field work. We went e.g. to Planica, the ski jumping world cup. I really liked the Turistica team I worked with there on the research about attitudes and experiences of visitors. Another interesting field work was to visit Strunjan Nature Park and Rodica winery visit, where they presented their sustainable tourism aspects. Besides the study I won't forget the events like ice hockey matches, concerts in Koper, social activities like international evenings, movie nights, polyglot cafe and other ESN events. And of course, the trips around Istria and the whole Slovenia were just amazing. I would like to express that I am very happy because I could be a part of Turistica. I am thankful to the whole Turistica team, teachers, students, coworkers!' Márk Répászky, incoming Erasmus student (Hungary)

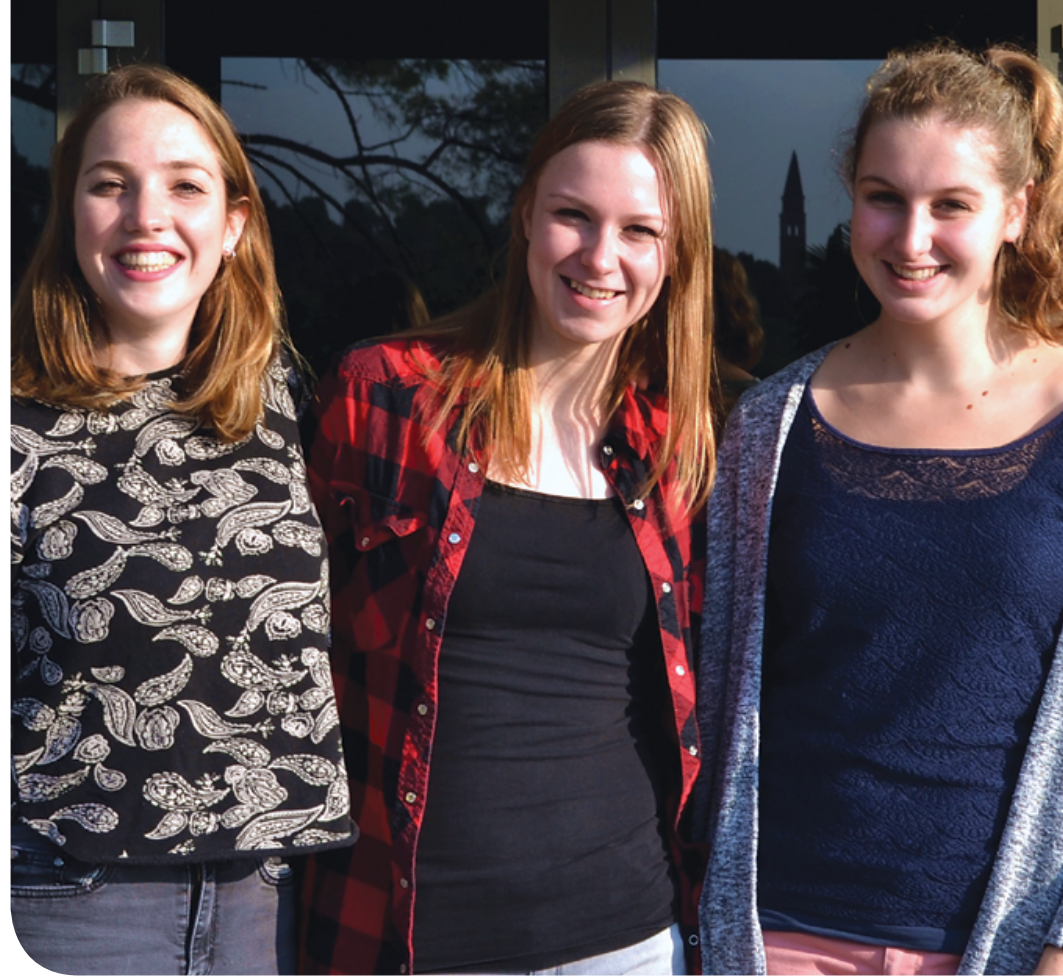

"Coming to a new country with new people was an adventure for all of us. We all knew very little about Slovenia. Throughout this semester we have learned a lot of new interesting things about tourism. This Erasmus exchange is such a great experience. It gave us a lot of great memories and new knowledge. Turistica really surprised us. It is so much smaller than our faculty in Breda and here there is a different kind of environment, more Mediterranean. Smaller, but still very cozy. We are glad to say that going to Slovenia and choosing Turistica was a really good decision. Since it all changed a little bit of us." Meta Austen, Lisanne de Groot and Carline Vonk, incoming Erasmus students (Breda, The Netherlands) 


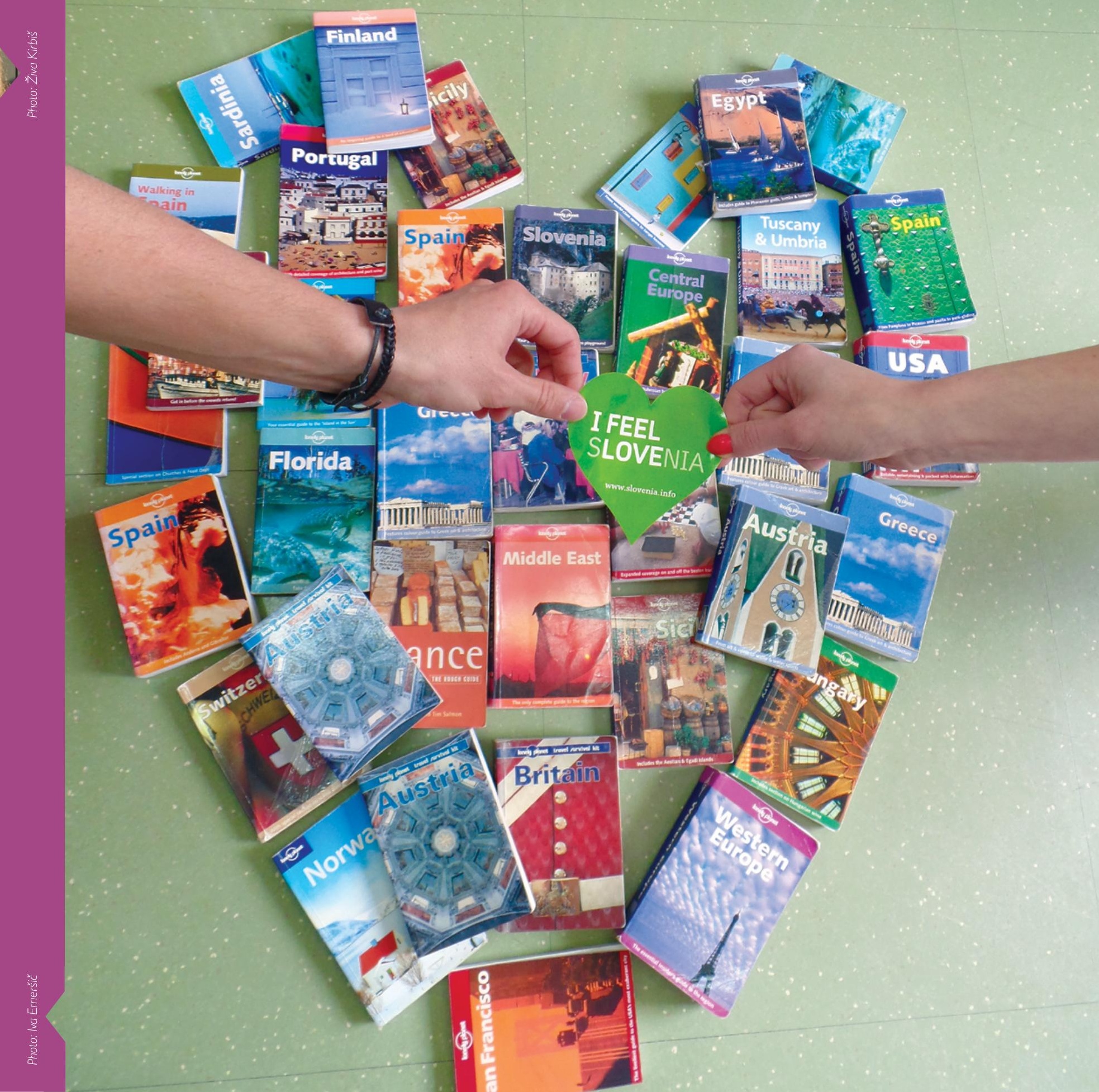



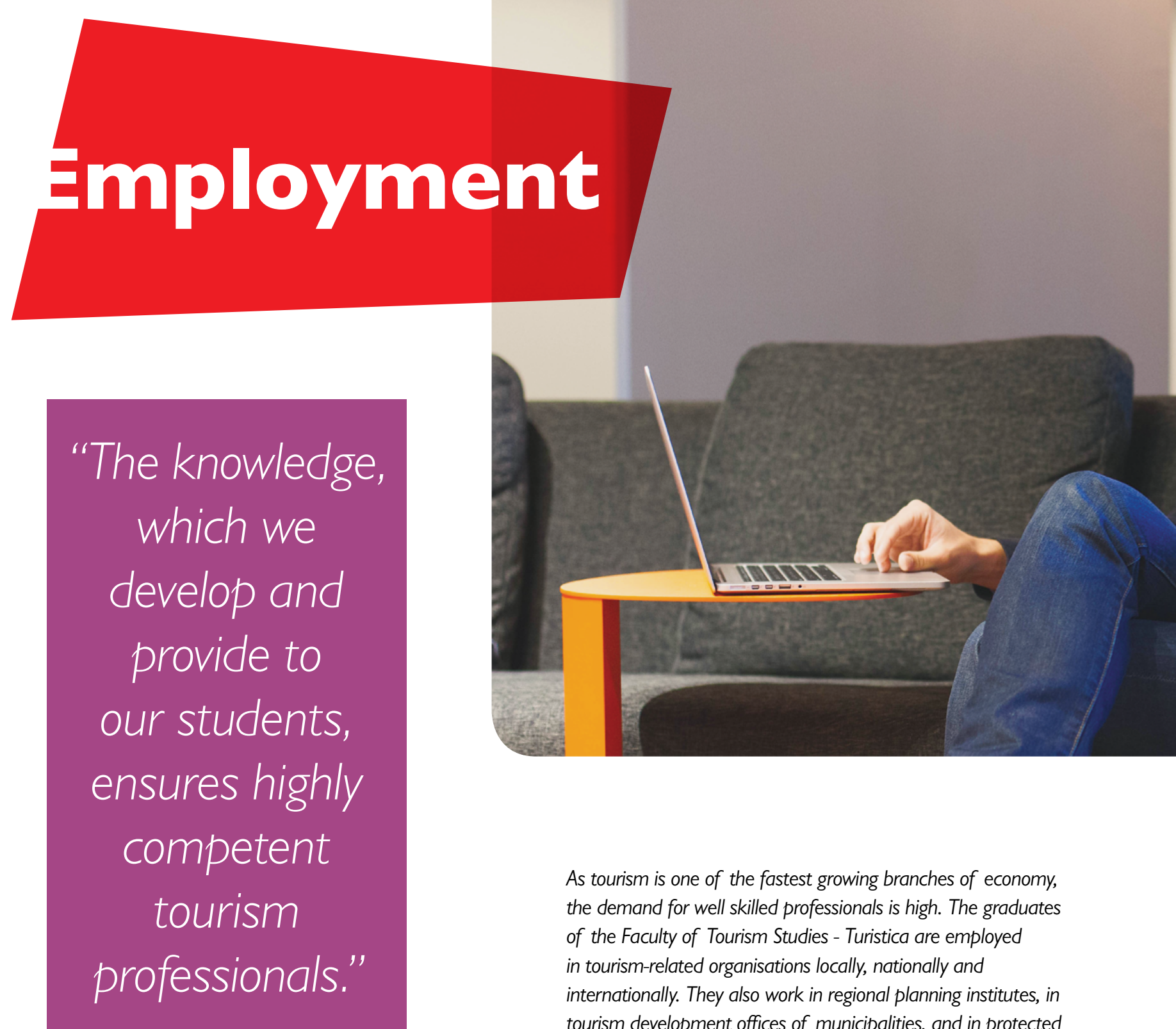

As tourism is one of the fastest growing branches of economy, the demand for well skilled professionals is high. The graduates of the Faculty of Tourism Studies - Turistica are employed in tourism-related organisations locally, nationally and internationally. They also work in regional planning institutes, in tourism development offices of municipalities, and in protected 
areas of nature and culture. Being able to work both in management as well as in research, they can cover a variety of positions going from working in the branch of hospitality to organization of events, cultural organizations and in the complementary tourist offers such as congress or wellness tourism. A high quality and varied offer of foreign languages study enables our students to compete for job positions, which demand foreign language knowledge and communication skills at home as well as abroad. Furthermore, the graduates of Turistica are very competitive on labour market. There is a strong connection between the faculty and the tourism companies which enables the use of internship periods as a compulsory part of some study curriculums.

\section{Tourism is one of the fastest growing branches of economy and thus enables a wide variety of possible employments.}




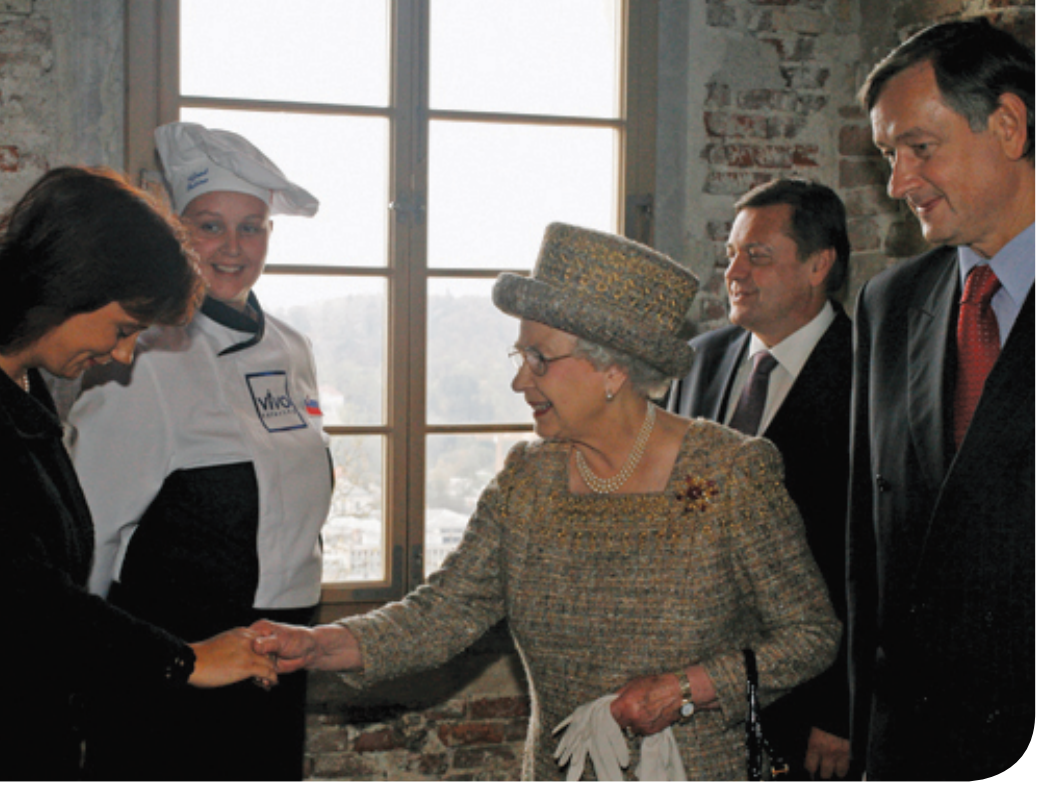

the leading and well known catering companies in Slovenia and South-eastern Europe, Vivo d.o.o., considers her greatest success to be the lunch that was organised in cooperation with her company to host the English queen Elizabeth II. The greatest motivation for a successful start of a day is her morning coffee, whereas tourism motivates her because of its diversity. She has fond memories of Turistica, one of her favourite is the memory of taking the English language exam. Her advice to students at Turistica would be to enjoy and network during the study years.

The company is proud of every event, especially when hosting eminent guests, like Queen Elizabeth II, former USA president Bill Clinton, celebrities like Kevin Costner, Monica Belluci, David Guetta, etc.

Gregor Povalej, the CEO of Kompas Touristik International, $\mathrm{Kft}$. in Budapest, considers the employment at Kompas abroad as his greatest business success. In his opinion, that was enabled by being a graduate of Turistica's first generation. The biggest obstacle in his career was learning how to be patient with his previous employers. Nevertheless he tried to learn from them as much as possible and that lead to "his one key moment". His advice to future students at Turistica would be to study hard, especially languages. 


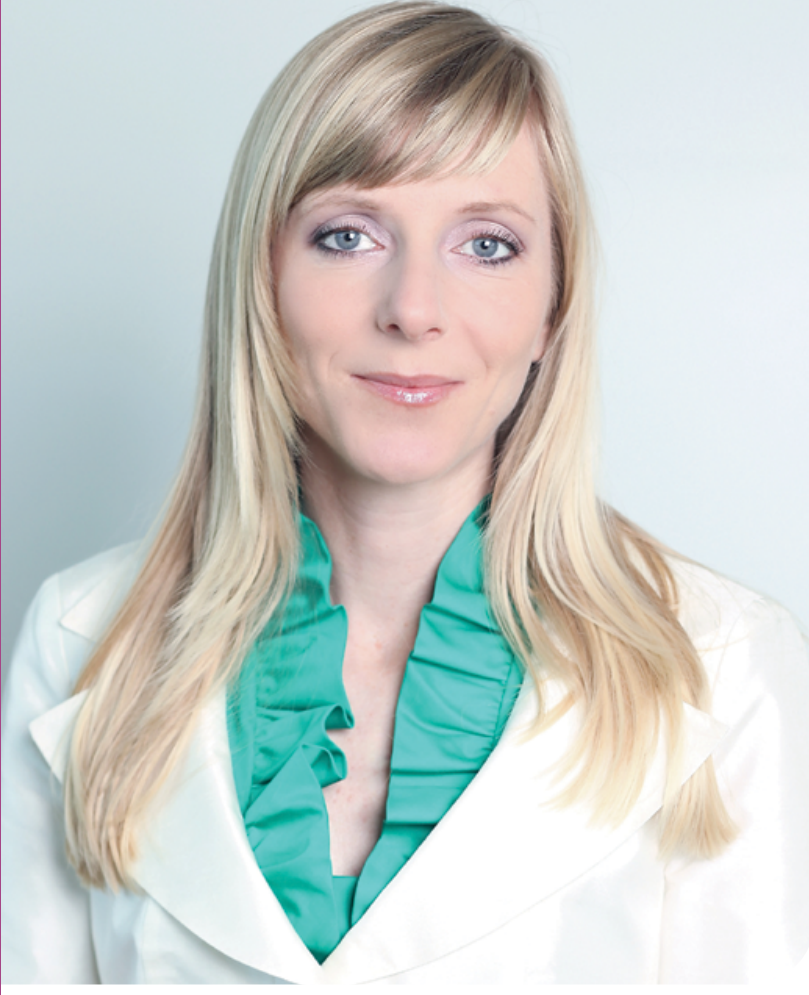

Karmen Novarlič, head of Business Communication Department at the Slovenian Tourist Board (STO), established first charter flights from Japan to Slovenia, brought many ministers dealing with tourism after the independence as well as the highest China National Tourism Administration to participate at the ministries meeting on tourism among the middle and eastern European countries and China. She says that those kinds of business events represent her biggest success. She adds that progression

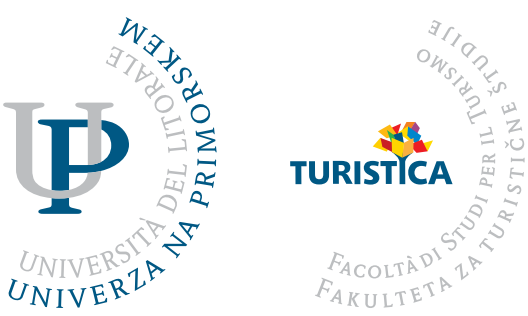

in career was an obstacle for her, which she overcame by gaining knowledge, suitable abilities and with hard work. Working with people, multiculturalism and a dynamic environment of tourism makes her happy, what can be seen in her motivation which she gets daily in new promotional projects for Slovenia abroad. Despite all this she takes time to relax in sports activities in nature. She loves to explore Slovenia but outside of our country she is drawn to Asia. She thinks of herself as a positive person because she believes that solutions can always be found. Her friend would also describe her as positive, persistent and reliable but also a little bit too busy all the time. As a former student of Turistica's first generation she remembers genuine, open and really good relations with the lecturers. Her advice to following generations at Turistica would be: "Upgrade the theory with practice and do as many student works in tourism as you can, because that will help you in your future career." 


\section{Enrolment for foreign citizens}

Foreign citizens and Slovenes without Slovene citizenship can apply and enrol to the University of Primorska in accordance with the requirements and criteria assigned by the Higher Education Act, Rules on Studies pursued by foreign citizens and Slovene Nationals without Slovenian Citizenship in the Republic of Slovenia, the Statute of the University of Primorska, the Pre-enrolment announcement and the Rules on preenrolment announcement and enrolment in higher education.

Those foreign citizens with permanent residence in Slovenia who (or whose parents) are taxpayers in Slovenia and citizens of the European Union are subject to the same application procedure as citizens of the Republic of Slovenia.

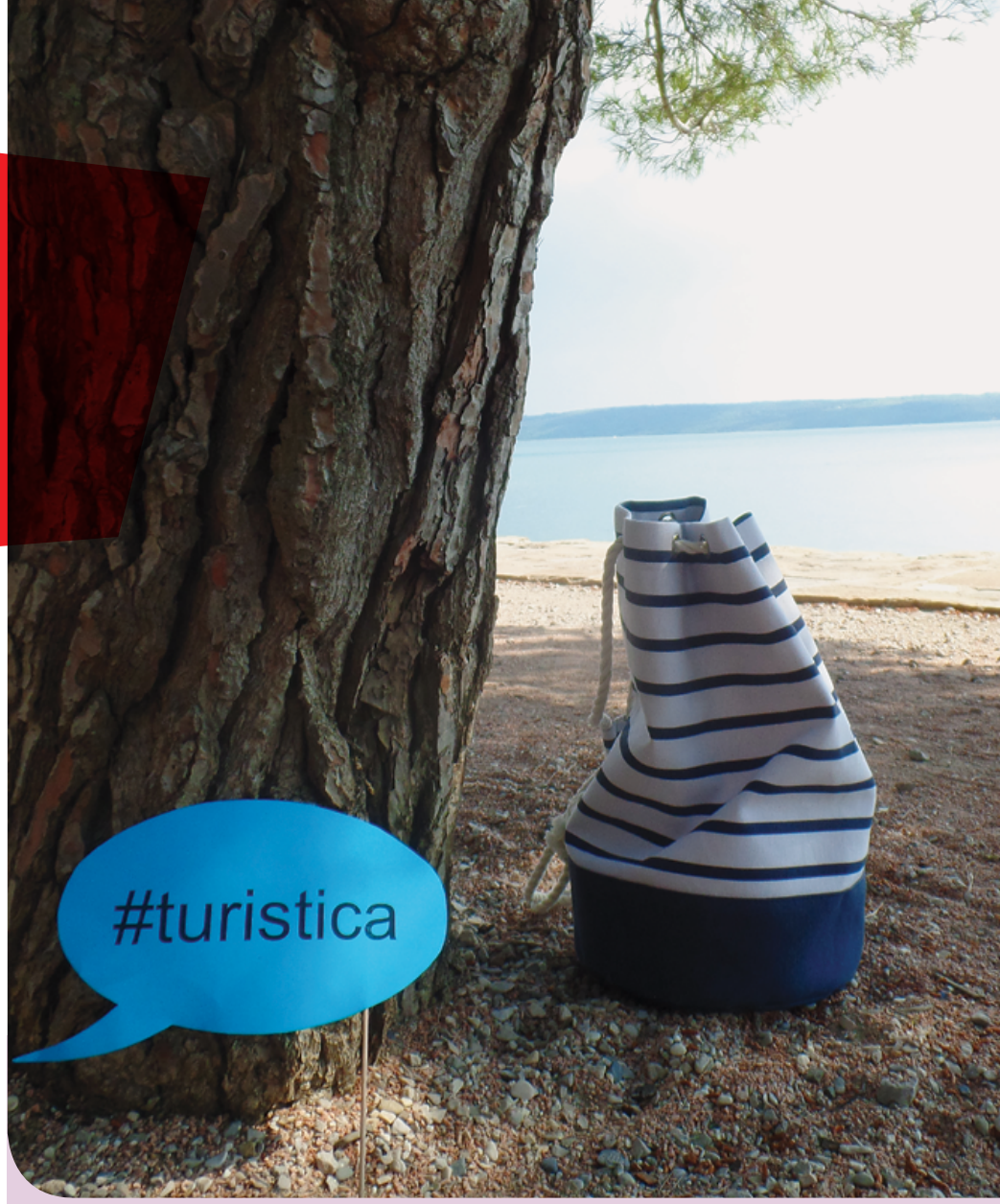

Admissions Office of the University of Primorska (VPIS UP)

Titov trg 4, SI-6000 Koper

E-mail:vpis@upr.si, student.office@upr.si 


\section{NOTES}




\section{NOTES}


NOTES 


\section{NOTES}


NOTES 


\section{NOTES}




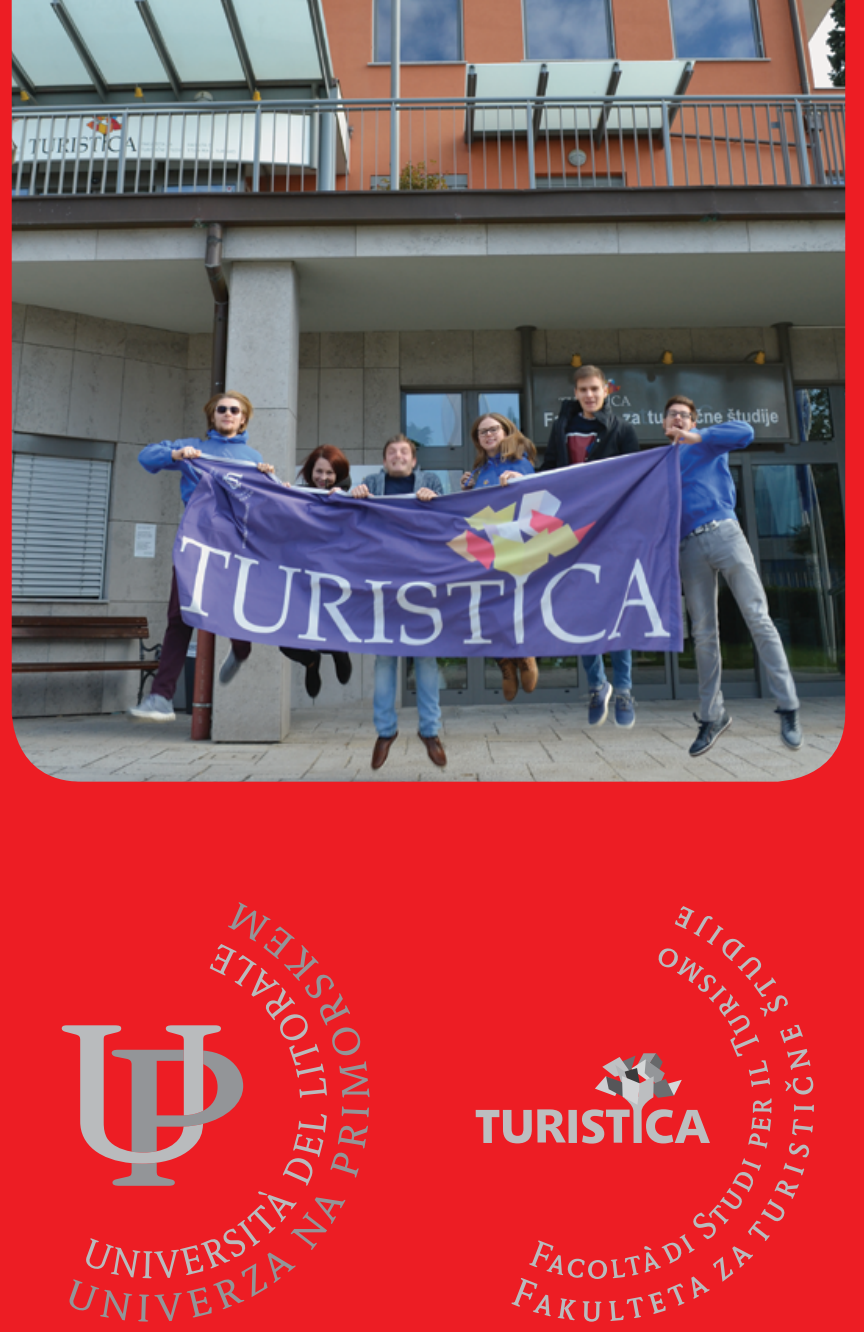

Univerza na Primorskem/University of Primorska Fakulteta za turistične študije Turistica/Faculty of Tourism Studies Turistica

More information:

i www.turistica.si

- Obala IIa, 6320 Portorož, Slovenia

f@UPFTSTuristica

@info@fts.upr.si

우@ftsturistica

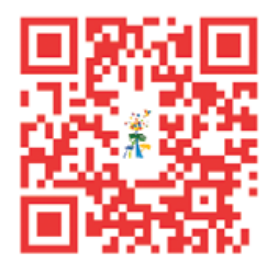

